\title{
MASKI Z OPOLA W KONTEKŚCIE OBRZĘDOWOŚCI ŚREDNIOWIECZNYCH SŁOWIAN
}

\begin{abstract}
Abstrakt: Nadrzędnym celem artykułu jest analiza podstaw źródłowych oraz interpretacyjnych dotyczących tzw. masek z Opola. Przedmioty te na stałe weszły do studiów nad religią przedchrześcijańską Słowian Zachodnich, szybko osiągając status ikonicznych. Tym, co wzbudza zaskoczenie, jest widoczna w literaturze, w zasadzie bezkrytyczna akceptacja identyfikacji obu omawianych przedmiotów, jaką ponad półwiecze temu zaproponowała Helena Cehak-Hołubowiczowa. Żaden z późniejszych autorów nie podjął się polemiki z tymi ustaleniami, co w konsekwencji doprowadziło do ugruntowania badawczego paradygmatu. Maski z Opola stały się również podstawą do rozwijania rozmaitych hipotez dotyczących pogańskich form obrzędowości na ziemiach polskich we wczesnym średniowieczu. W prezentowanym tekście podjęto próbę rewizji dotychczasowych interpretacji oraz krytyki budowanych na jej fundamencie hipotez.
\end{abstract}

Słowa kluczowe: wczesne średniowiecze, Słowianie, Śląsk, Opole, maski, obrzędowość

Abstract: An analysis of the source and interpretation base for the so-called masks from Opole is the prime objective of this article. These objects became a part of studies on the religion of the Western Slavs in pre-Christian times and quickly took on iconic status. However, the virtually uncritical acceptance of the identification of these two artifacts, proposed more than half a century ago Helena Cehak-Hołubowiczowa, is surprising at the very least. None of the later researchers questioned the findings, thus entrenching the research paradigm. The masks from Opole have also been used to develop a variety of ideas concerning pagan rites in Polish lands in early medieval times. The article undertakes a revision of currently accepted interpretations and a critique of theories put forward on their basis.

Keywords: early Middle Ages, Slavs, Silesia, Opole, masks, magic/religious rites

a Dr Kamil Kajkowski, Muzeum Zachodniokaszubskie w Bytowie, ul. Zamkowa 2, 77-100 Bytów, kamilkajkowski@wp.pl, ORCID iD: https://orcid.org/0000-0001-9538-0963. 


\section{WSTĘP}

W latach pięćdziesiątych XX w. w Opolu zainicjowano badania archeologiczne, których celem było rozpoznanie reliktów wczesnośredniowiecznego grodu na tzw. Ostrówku. Kontynuowane przez wiele kolejnych lat prace wykopaliskowe przyniosły wiele informacji pozwalających na analizę i rekonstrukcję dawnych struktur osadniczych. Dostarczyły też niezwykle bogatego zespołu przedmiotów stanowiących świadectwo obecności i zajęć, jakim poświęcali się ówcześni mieszkańcy osiedla. Tym, co zwraca szczególną uwagę, a jednocześnie wyróżnia badania w Opolu, są doskonale zachowane przedmioty wykonane $\mathrm{z}$ materiałów organicznych naświetlające kolejne aspekty życia społeczności zamieszkującej gród. Pośród nich wyróżniono również i takie, które miały dowodzić rozmaitych zabiegów obrzędowych odzwierciedlających potrzeby duchowe jednostek bądź grup ludzkich. Oprócz figurki konika, pisanek/skorup jaj, zoomorficznych wycinanek, rozmaitych szczątków zwierzęcych i wielu innych, na Ostrówku wydobyto dwa przedmioty o trudnej do sprecyzowania funkcji, które ze względu na rozmiary oraz cechy kojarzące się archeologom z ludzką twarzą uznano za destrukty wczesnośredniowiecznych masek obrzędowych (Cehak-Hołubowiczowa 1965). Taki sposób interpretacji nadawał odkryciu status wyjątkowości i pozostawał bezprecedensowy w skali Polski, a nawet Słowiańszczyzny Zachodniej.

\section{OPOLSKIE REWELACJE}

Omawiane przedmioty odkryto podczas dwóch sezonów badawczych, prowadzonych w latach 1959 i 1962. Sposób i kolejność prezentacji obu odkryć (Cehak-Hołubiczowa 1965) nie pozostawiają wątpliwości, że okaz późniejszy dał asumpt do przypisywanej im funkcji. Jest to przedmiot wykonany z drewna sosny (ryc. 1). Mierzy $34 \mathrm{~cm}$ długości przy największej szerokości 20 i najmniejszej 7,2 cm. Grubość deski, z której go wycięto, wahała się między 3,7 a 5,3 cm. Ważnym szczegółem są cechy metryczne dotyczące sposobu wykończenia „wewnętrznej” i „zewnętrznej” części przedmiotu. Do wynikających z nich implikacji wrócimy w odpowiednim momencie. Tutaj odnotujmy jedynie, że jeśli część „twarzowa” jest odrobinę wypukła i obrobiona na gładko, to „rewers” jest płaski i cechujący się gorszym wykończeniem. W szerszej partii przedmiotu wywiercono dwa równolegle rozmieszczone otwory, które Helena Cehak-Hołubowiczowa uznała za oczodoły. Trzeci, umieszczony w zwężającej się części, czy - jak chce badaczka - powyżej „spiczastej bródki”, miał odpowiadać ustom (jednak z zastrzeżeniem, że umieszczono go zbyt nisko w stosunku do ludzkiej fizjonomii). Kolejną wskazówką przemawiającą, jej zdaniem, za antropomorficznym charakterem tego przedstawienia jest biegnąca mniej więcej przez środkową część przedmiotu wyżłobiona „kreska”. Uważała, że jest ona wynikiem intencjonalnego zamysłu, wedle którego poprowadzoną od dolnej linii „oczodołów”, biegnącą pionowo niemal do „dolnego” otworu i zakręcającą bruzdę umieszczono w celu zaznaczenia (widzianego z profilu) nosa (Cehak- 


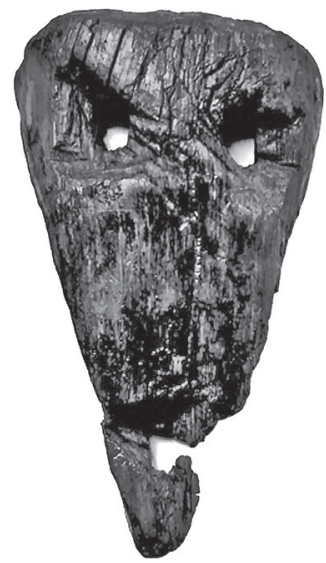

0

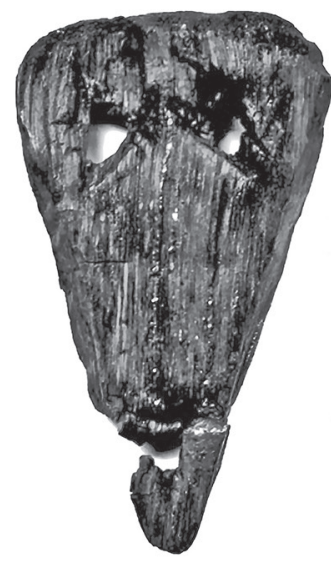

$10 \mathrm{~cm}$
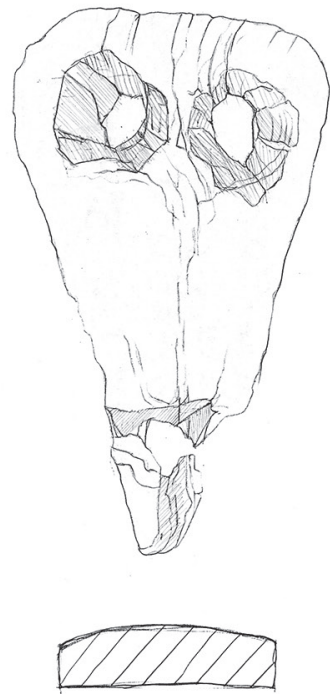

Ryc. 1. Opole-Ostrówek, drewniana „maska” z 3 ćwierci XI w.

Wg archiwum Ośrodka Badań nad Kulturą Późnego Antyku i Wczesnego Średniowiecza IAE PAN we Wrocławiu; opracował K. Szott

Fig. 1. Opole-Ostrówek, wooden "mask" from the $3^{\text {rd }}$ quarter of the $11^{\text {th }} \mathrm{c}$.

From the archive of the Center of Research on Late Antique and Early Medieval Culture, Institute of Archaeology and Ethnology, Polish Academy of Sciences, Wrocław Branch; processing by K. Szott

-Hołubowiczowa 1965, s. 307). Z toku wypowiedzi badaczki można odnieść wrażenie, że wyjątkowość „maski” podkreślają również zaobserwowane na powierzchni "smugi" czerwonego barwnika, który pierwotnie pokrywał najprawdopodobniej całą jej powierzchnię. Z kolei wyraźnie widoczne niestaranne wykończenie miałoby dowodzić pośpiechu, a tym samym zaświadczać, że „twórca nie przykładał większej wagi do walorów wypływających z estetycznego wyglądu swego dzieła" (Cehak-Hołubowiczowa 1965, s. 307). Zinterpretowanie przedmiotu jako maski pozwoliło uznać, że została „zachowana prawie w całości”, a jej rozmiary „dostosowane do zakrycia twarzy człowieka" (Cehak-Hołubowiczowa 1965, s. 305).

Pierwszą z odkrytych „masek” zarejestrowano w nawarstwieniach, których charakter tworzyła próchnica i drzazgi. Według ustaleń H. Cechak-Hołubowiczowej była to warstwa śmietniskowa, najpewniej związana $\mathrm{z}$ jedną $\mathrm{z}$ chat (nr 19), wtórnie nakryta dranicami służącymi jako trakt pomiędzy budynkami (ryc. 2). W tym samym kontekście stratygraficznym odnotowano obecność innych przedmiotów 


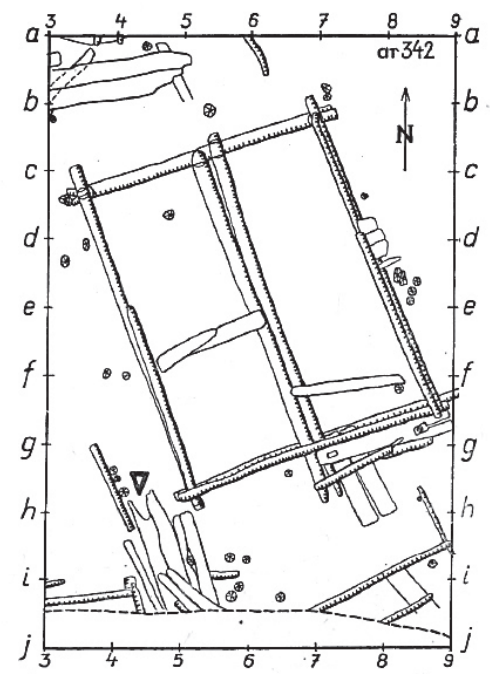

Ryc. 2. Opole-Ostrówek, fragment planigrafii warstwy D2 z miejscem znalezienia starszej „maski” (oznaczonym trójkątem).

Wg Cehak-Hołubowiczowej 1965, ryc. 3

Fig. 2. Opole-Ostrówek, detail of the planigraphy of layer D2 marking with a triangle the findspot of the older "mask".

After Cehak-Hołubowiczowa 1965, Fig. 3

drewnianych (niewykończonej figurki zoomorficznej uznanej za wizerunek kozy/ kozła, płozę sań, kołek), ścinek skóry, ułamki ceramiki naczyniowej oraz kości zwierzęce. Chronologię całego zespołu określono na 2 poł. XI stulecia (Cehak-Hołubowiczowa 1965, s. 305).

Drugiego z opolskich odkryć (ryc. 3) dokonano w okolicach południowo-zachodniego narożnika reliktów młodszego budynku ( $\mathrm{nr} 20$ ), datowanego na schyłek XII stulecia (ryc. 4). W tej samej warstwie kulturowej odnotowano obecność fragmentów naczyń ceramicznych i kości zwierzęcych (Cehak-Hołubowiczowa 1965, s. 308). Zabytek, tym razem z drewna brzozy, znaleziono uszkodzony - brakuje części określonej jako „bródka”. Zachowana długość wynosi $23 \mathrm{~cm}$, natomiast szerokość $18 \mathrm{~cm}$ w najszerszym i 6,3 cm w najwęższym miejscu. Grubość waha się między 1,7 a $2,3 \mathrm{~cm}$. Podobnie jak w przypadku pierwszego egzemplarza, także i ten pierwotnie zaopatrzony był w trzy otwory, którym autorka opracowania przydała analogiczne funkcje. Cechą odróżniającą oba egzemplarze jest odmienny sposób obrobienia „wewnętrznej” powierzchni. W przypadku omawianego okazu została ona wygładzona, zaś partia przeciwna niedokładnie obrobiona, skutkiem czego powierzchnia jest nierówna i pokryta zgrubieniami po sękach. Na części „zewnętrznej" widoczna jest pionowa bruzda biegnąca wzdłuż dłuższej osi przedmiotu. W opinii H. Cehak-Hołubowiczowej wykonano ją umyślnie, w celu programowego podziału „maski” na dwie połowy, natomiast nierówny jej przebieg badaczka tłumaczy właściwościami sękatego drewna, uniemożliwiającego umieszczenie linii dokładnie w środkowej części (Cehak-Hołubowiczowa 1965, s. 309). Porównanie cech metrycznych przedmiotu, podobnie jak poprzednio, pozwoliło uznać, że także drugi, nieco mniejszy i lżejszy zabytek przygotowano w taki sposób, aby mógł zakryć całą twarz (Cehak-Hołubowiczowa 1965, s. 309-310). 

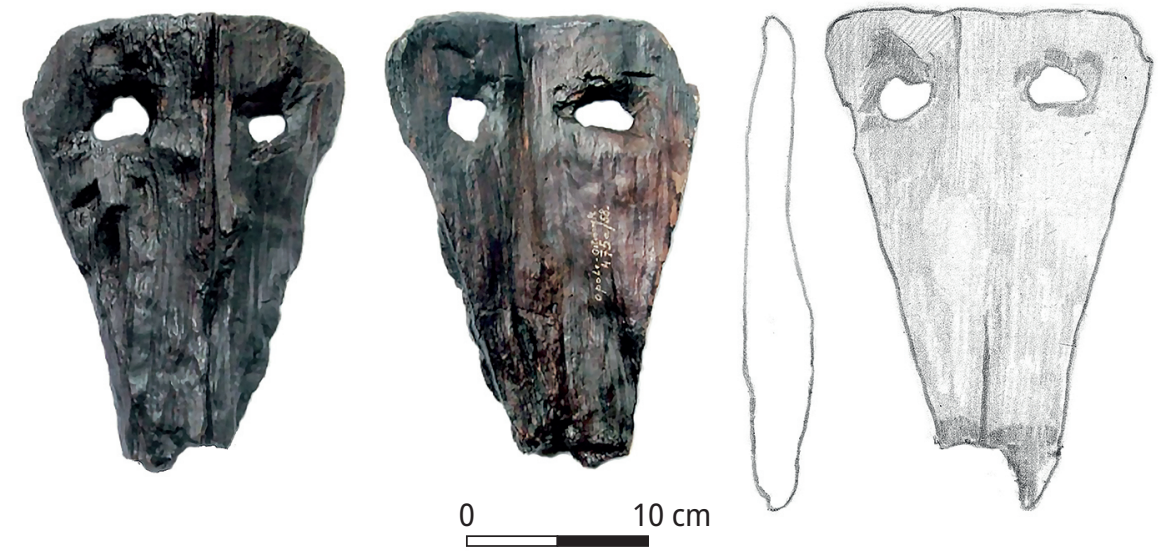

Ryc. 3. Opole-Ostrówek, drewniana „maska” z połowy XII w.

Wg archiwum Ośrodka Badań nad Kulturą Późnego Antyku i Wczesnego Średniowiecza IAE PAN we Wrocławiu; opracował K. Szott

Fig. 3. Opole-Ostrówek, wooden "mask" from the mid-12 $2^{\text {th }} \mathrm{c}$.

From the archive of the Center of Research on Late Antique and Early Medieval Culture, Institute of Archaeology and Ethnology, Polish Academy of Sciences, Wrocław Branch; processing by K. Szott

Ryc. 4. Opole-Ostrówek, fragment planigrafii warstwy A6 z miejscem znalezienia młodszej „maski” (oznaczonym trójkątem).

Wg Cehak-Hołubowiczowej 1965, ryc. 5

Fig. 4. Opole-Ostrówek, detail of the planigraphy of layer A6 marking with a triangle the findspot of the younger "mask" After Cehak-Hołubowiczowa 1965, Fig. 5

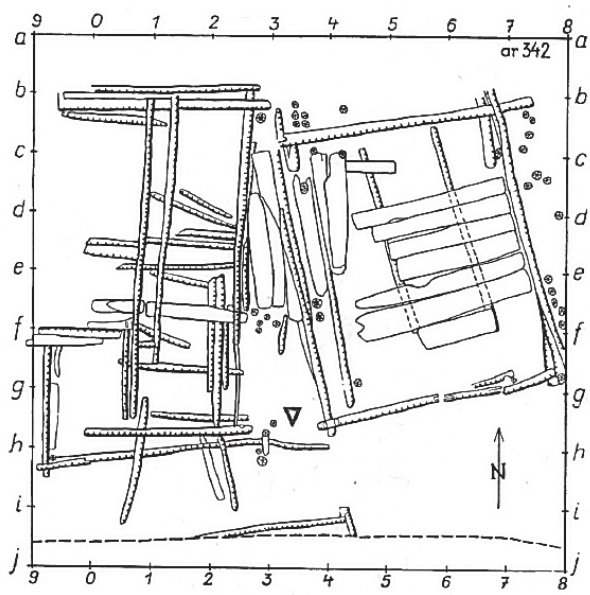

Szczegółowa analiza argumentów i hipotez stawianych przez Helenę Cehak-Hołubowiczową zdradza wiele nieścisłości i wymaga krytycznego komentarza. Ponieważ jest to problem wielowątkowy i bardziej skomplikowany, niż się wydaje 
na pierwszy rzut oka, należy go ująć w szerszym aspekcie, zarówno teoretycznym, jak źródłoznawczym.

Zaczniemy od zdefiniowania, co skrywa się, czy też precyzyjniej - co będziemy rozumieć pod pojęciem maski. W dalszej kolejności przyjrzymy się średniowiecznym źródłom pisanym, ikonograficznym i archeologicznym. Zobaczymy również, jak „maska” z Opola sprawdza się w przypisywanej jej funkcji.

\section{CZYM JEST MASKA?}

Wśród badaczy panuje przekonanie, że tradycja zakładania masek znana była najstarszym społecznościom ludzkim żyjącym w epoce kamienia (Gunnell 2007, s. 27). Już wówczas miała ona wynikać $\mathrm{z}$ archetypicznego sposobu postrzegania rzeczywistości (Porębska-Kubik, Marcinkowska 1992, s. 3), jednocześnie stanowiąc jedno z „pierwotnych narzędzi” jej percypowania (Kerényi 2010, s. 684). W takim kontekście z reguły przeciwstawia się ją twarzy, będącej podstawowym narzędziem w interakcji międzyludzkiej, przekazującym nie tylko treść artykułowanego komunikatu, ale zasadnicze dla niego elementy indywidualności, a zarazem wiarygodności komunikującego (Paluch 1995, s. 157; Gunnell 2012, s. 190; Larson 2017, s. 317; Urbańczyk 2020, s. 157). Maska jako przedmiot pozbawiony takich właściwości wywołuje uczucie niepewności, a powodując nieobecność czynnika osobowościowego (człowieczeństwa), skojarzona została ze światem nie-ludzkim. Zarówno to, jak również ze względu na wyrażane cechy antropomorficzne kojarzona bywała ze zmarłymi. To z kolei nadawało jej funkcji operatywności, czyniąc z niej środek umożliwiający nawiązanie łączności z krainami zaświatowymi (Kerényi 2010, s. 684-685). I właśnie w takiej roli widzimy ją w antycznej Grecji i Rzymie, gdzie jak dziś zwykło się uważać - działania obrzędowe podejmowane ku czci przodków dały fundament pod rozwój i charakter sztuk teatralnych (Harntoll red. 1967, s. 623; Kolankiewicz 2020, s. 34-35).

Obie te własności odnajdujemy w łacińskiej średniowiecznej terminologii używanej na określenie maski, nazywanej takimi słowami jak masca, larva czy persona. Pierwszemu z nich Aleksander Brückner (1985, s. 324) przypisał związek z maszkarami/komediantami. Drugi łączył z polskim słowem larwa, jakim określano nie tylko maskę ${ }^{1}$, ale także marę/maszkarę, co niesie dalsze ciekawe konotacje. Analizując wskazane związki lingwistyczne, wypada odnotować, że mara (w znaczeniu „widziadło senne, urojenie, marzenie”) wywodzone jest od niosącego podobne treści prasłowiańskiego dialektalnego * mara, które z kolei może pochodzić od praindoeuropejskiego *mer („błyszczeć, lśnić, migać”, ale także „mrzeć, umierać). Ten ostatni wykazuje związki z prasłowiańskim ${ }^{*}$ mŕtvr ('umarły, nieżywy'), jak również z łacińskim mortuus („zmarły, martwy”). Ustalenia te utwierdziły niektórych autorów w przekonaniu o immanentnym związku łączącym maskę ze śmiercią/ zmarłymi i pozwoliły uznać ten trop za „najważniejszy jakim powinniśmy zmie-

\footnotetext{
${ }^{1}$ Nomen omen do dziś w taki sposób nazywaną w języku kaszubskim.
} 
rzać, aby odczytać ich [tj. masek] rolę w religii pogańskich Słowian” (Szczepanik 2020, s. 170). Niedługo przekonamy się, czy tak arbitralnie postawiona teza znajduje pokrycie w źródłach. Teraz wróćmy jeszcze do średniowiecznych określeń opisujących maski, zwracając uwagę na inny łaciński termin mogący mieć związek ze wspomnianym larva. Mowa o słowie larvāre, które Andrzej Bańkowski (2000, s. 5) łączy z czynnością czarowania („czynić czary”). Niewykluczone, że oba określenia mogą wywodzić się ze wspólnego źródłosłowu związanego z indoeuropejskim rdzeniem *lä („,pozostawać w ukryciu”) (Kowalik 2004, s. 97). Zagadnienie to wymaga jednak dalszych badań, szczególnie w kontekście domniemanych związków wyrazu lala ze światem słowiańskich wyobrażeń mitologicznych lub/i eschatologicznych (Szafrański 1979, s. 362; Brückner 1985, s. 290; Szyjewski 2003, s. 199-200).

Analiza rezultatów dotychczasowej refleksji teoretycznej pozwala stwierdzić, że maska jest przedmiotem obdarzonym mocą transformacji i komunikacji (Lévi-Strauss 1985, s. 87; Olszewska-Dyoniziak 2001, s. 229; Gunnell 2007, s. 27). Prowadzone od wielu lat badania nad tym zagadnieniem pokazują, że przedmioty te pojawiają się w sytuacji mediacyjnej, kiedy „człowiek znajduje się na pograniczu dwóch rzeczywistości” (Porębska-Kubik, Marcinkowska 1992, s. 3; por. Gunnell 2007, s. 192). Tym samym odsłaniają i dają możliwość kontaktu ze światem na ogół niedostępnym ludzkiemu poznaniu, wzbudzając określone emocje, zarówno - by posłużyć się terminologią Rudolfa Otto (1993) - fascynacji, jak i strachu (por. Gunnell 2007, s. 28, przyp. 2; Kerényi 2010, s. 684; Schindler 2010, s. 431). Jednoczenie nie mamy podstaw, by sądzić, że włożenie maski powoduje inkarnację - nadaje noszącej ją osobie inną tożsamość, czy to zmarłego, czy też jakiejś istoty nadprzyrodzonej (por. Boholm 2010, s. 694). „Maska sytuuje się na dwuznacznej granicy pomiędzy ludzkim a 'boskim', między zróżnicowanym porządkiem ulegającym rozkładowi a jego niezróżnicowanym tamtym światem, który jest także miejscem wszelkich różnic" (Girard 1993, s. 231). Jeśli więc zadaniem maski jest nawiązanie łączności między światami, to należy ją uznać za przedmiot o dużej mocy performatywnej przeznaczony do działań rytualnych (por. Gunnell 2012, s. 183, 191), czynności umożliwiających nie tylko osiągnąć, ale także ową łączność utrzymać. Pozostaje zadać pytanie, czy zarysowany przez antropologów, religioznawców, teatrologów i lingwistów model interpretacji można zastosować do wyobrażeń i obrzędowości wczesnośredniowiecznych Słowian? Na początek przyjrzyjmy się, co na ten temat mówią źródła pisane.

\section{CIENIE ZMARŁYCH}

Z całego korpusu piśmiennictwa średniowiecza znajdziemy zaledwie jeden zapis dotyczący interesującego nas czasu i obszaru. Zawdzięczamy go kronikarzowi czeskiemu Kosmasowi, który - relacjonując wydarzenia związane z objęciem tronu czeskiego przez księcia Brzetysława (1092 r.) - z rozczarowaniem donosi o pogrzebach, „które odbywały się po lasach i na polach”, wspominając jeszcze „korowody, odprawiane podług pogańskiego zwyczaju, na dwóch i trzech rozstajnych drogach, 
jakby dla spokoju duszy” oraz „bezbożne igry, które [ich uczestnicy] odprawiali nad swoimi zmarłymi, tańczą [c] z założonymi na twarz maskami i wywołując cienie zmarłych" (Kosmas 2006, III, 1). Przekaz ten był już wielokrotnie analizowany przed badaczy wczesnośredniowiecznej obrzędowości pogrzebowej. Rzadko jednak poruszano przy tej okazji problem zakrywania twarzy przez uczestników gorszących kronikarza zabaw organizowanych nad grobami.

Wśród uczonych studiujących przekaz Kosmasa już Lubor Niederle zauważył podobieństwo czynności opisanych w „Kronice Czechów” do wschodniosłowiańskiej tryzny, w trakcie której, jak sądził, miały odbywać się walki oraz tańce z mieczami. Mimo że - czego nie omieszkał wytknąć mu A. Brückner - w swojej interpretacji „popuszcza wodze fantazji” (Brückner 1985, s. 268, 269), to jeśli rzeczywiście przyjęlibyśmy jej zasadność, hipoteza czeskiego historyka może znaleźć potwierdzenie w badaniach lingwistycznych. Okazuje się bowiem, że w języku starocerkiewnosłowiańskim słowo „trizna” tłumaczy się jako „bój, walka, igrzyska”, „nagroda w zawodach". Konkludując przytoczone ustalenia, Leszek Kolankiewicz uznał, że „tryzną były [...] turnieje urządzane przez Słowian przed samą strawą, czyli stypą, być może jeszcze nad ciałem zmarłego" (Kolankiewicz 2020, s. 296; por. Bylina 1992, s. 9-10). Są to jednak domysły nie znajdujące bezpośredniego potwierdzenia w treści źródła. W związku z tym musimy zgodzić się z opinią Stanisława Urbańczyka (1980, s. 195) wykazującego brak podstaw do bardziej szczegółowych spekulacji. To co możemy wyczytać $z$ analizowanego fragmentu, a jednocześnie uznać za (mniej lub bardziej) prawdopodobne, to informacje, że obrzędy odprawiano "nad zmarłymi oraz że tańczono z założonymi maskami”. Pierwsza, wraz z wcześniejszym uzupełnieniem o miejscu chowania przodków, wyraźnie wskazuje cmentarz jako scenerię opisywanych wydarzeń. Druga mówi o dobrze znanym i powszechnym w obrzędowości przedchrześcijańskiej elemencie, jakim były rytualne pląsy (por. Kajkowski 2017, s. 173-194) oraz wykorzystywaniu w niej masek. Nie wiemy jednak, ani jak te przedmioty wyglądały, ani też ile ich było ${ }^{2}$. Jeżeli zgodnie z treścią źródła zebrani rzeczywiście przywoływali duchy zmarłych, to - podpierając się tym co wiemy na temat prawideł rytuału - podczas wykonywania tych czynności mogli być narażeni na trudny do przewidzenia wpływ sił nadprzyrodzonych. Otwarcie wrót do „tamtego” świata naruszało też integralność doczesnego. I nawet jeśli docelowo przynosiło korzyści wspólnocie, to moment przywoływania przodków mógł stwarzać realne niebezpieczeństwo dla osób naruszających równowagę Kosmosu. W takim przypadku w maskach możemy domyślać się nie tylko przedmiotów o charakterze mediacyjnym, ale także środków ochronnych zabezpieczających przed konsekwencjami podjętych czynności (por. Bylina 1992, s. 9)³.

${ }^{2}$ Tym bardziej trudno odpowiedzieć, dlaczego Leszek Kolankiewicz uznał, że opisani przez Kosmasa uczestnicy „igrów” byli „przystrojeni w o k r o p n e [rozstrzelenie - K.K.] maski” (Kolankiewicz 2020, s. 298).

${ }^{3}$ Pośrednią wskazówką mogącą potwierdzać taki tok rozumowania są informacje dotyczące nowożytnych obrzędów zaduszkowych, których uczestnicy zasłaniali twarze, „aby upiór nie rozpoznał swych krewnych i po nich nie przyszedł" (Odyniec 1985, s. 77; por. Kucharska 1991, s. 14). Trzeba jednak wyraźnie podkreślić magiczny charakter tych czynności. Wrócimy do tego w końcowej części tekstu. 
Możliwe jednak, że wspomniane „cienie” przodków to element retoryki kronikarza odwołującego się do tradycji antycznej ${ }^{4}$. W takim przypadku Kosmas niekoniecznie musiał oddać właściwy sens opisywanego obrzędu. Jednak nawet jeśli "zakrzywił” kryjące się za nim treści światopoglądowe, to przecież opis czynności towarzyszących rytuałowi znamion erudycyjnych popisów już nie nosi. Jeśli zaś ten (zgodnie z ustaleniami religioznawców) ma być reaktualizacją wydarzeń mitycznych, to jego wyjaśnienia powinniśmy poszukać we wczesnośredniowiecznych zachodniosłowiańskich wyobrażeniach kosmologicznych i/lub eschatologicznych. Na podstawie obecnego stanu wiedzy można przyjąć, że zmarli (a zapewne i niektóre istoty nadprzyrodzone) mogli przybierać w nich formy zoomorficzne (Gardeła, Kajkowski, Ratajczyk 2019). O ile więc uczestnicy opisywanych przez Kosmasa wydarzeń rzeczywiście „odgrywali” sceny o charakterze mitologicznym, to należy założyć, że bardziej odpowiednim rekwizytem byłyby w nich jednak maski zwierzęce.

\section{LUDI THEATRALES}

Jako że przekaz Kosmasa jest jedynym źródłem epoki jakim dysponujemy dla obszaru Słowiańszczyzny Zachodniej interesującego nas okresu' ${ }^{5}$, autorzy podejmujący problem obecności masek w obrzędowości tych społeczności na ogół sięgają do zapisów późniejszych (ze schyłku wczesnego bądź już późniejszego średniowiecza). Najstarszym jest list papieża Innocentego III do arcybiskupa Henryka Kietlicza z 1207 r., w którym nadawca potępia zwyczaj „przedstawień teatralnych” odbywanych w kościołach (Schmitt 2006, s. 280). Papież wskazuje tutaj nie tylko rekwizyty w postaci „potwornych masek” (monstris larvarum), ale także „obsceniczne gesty" towarzyszące obchodom (ludi theatrales), w których brało udział całe lokalne duchowieństwo (por. Burchardt 1986, s. 35).

Nieco ponad dwie dekady później (1230 r.) kolejny papież, Grzegorz IX, wystosował dwa listy adresowane do zakonów działających w Polsce. Podkreślał w nich brak tolerancji dla sposobu obchodów świąt okołonoworocznych, pośród których wyliczał zwyczaje polegające na przywdziewaniu masek i sprośne gesty/ruchy. Także i tym razem czynnie lub biernie uczestniczyli w nich przedstawiciele Kościoła (Kolankiewicz 2020, s. 316).

Rzadziej w badaniach zajmującego nas problemu wskazuje się na źródła nieco późniejsze, datowane od 2 poł. XIII w. Pierwszym zapisem, któremu warto poświęcić nieco uwagi, jest list, jaki w 1268 r. polski matematyk i filozof Witelo napisał do

${ }^{4}$ Cienie przodków pojawiają się m.in. w X i XI pieśni Odysei (Homer 2000, s. 115, 117, 121-122). Zamieszkujące sumeryjskie, greckie czy judeochrześcijańskie krainy zaświatowe ukazane zostały jako, jak to ujął Arnold Toynbee, „blade sobowtóry zmarłej już osoby” (Toynbee i in. 1973, s. 134).

${ }^{5}$ Co prawda „Żywot z Prüfening” Ottona z Bambergu (VP II, 17) wspomina o zorganizowanych w Wolinie „przedstawieniach scenicznych zmieszanych z gwarem i hałasem”, w których możemy domyślać się jakiejś choreografii, jednak definitywne rozstrzygnięcie obecności w nich masek nie jest na gruncie treści źródła możliwe. 
Ludwika we Lwówku Śląskim. Poza problematyką kosmologiczną czy medyczną znajdujemy w nim fragment opisujący maski i figury wykorzystywane w obchodach noworocznych. Po raz pierwszy poznajemy więcej szczegółów dotyczących ich wyglądu. Uczony wskazał bowiem, że były to przedmioty wyobrażające zwierzęta w tym konkretnie przypadku jelenie i konie (larvari et figuras animalium assumere, ut equorum et cervorum) (Witelo 1979).

Niespełna dekadę później w piśmiennictwie kościelnym pojawia się kolejny interesujący szczegół dotyczący obchodów świąt Bożego Narodzenia. W 1279 r. na synodzie w Budzie wydano konstytucje, w których legat papieski do Węgier i Polski, Filip z Fermo, pod karą ekskomuniki zabrania księżom udziału, a wręcz przewodzenia korowodom oprowadzanym po cmentarzach i wewnątrz kościołów (Kolankiewicz 2020, s. 297). Co prawda nie ma tutaj mowy o maskach czy przybranych w nie figurach, jednak zarówno czas, miejsce, jak i charakter obchodzonych świąt sugerują, że mogły być używane (choć dalej poza domysły wyjść tutaj nie sposób). W tym kontekście ważnego dla nas wydźwięku nabiera czas oraz miejsce piętnowanych wydarzeń.

Z 1 ćwierci XIV w. pochodzi treść konstytucji synodu prowincjonalnego arcybiskupa Janisława w Uniejowie (1326 r.) nakazująca, „aby jacykolwiek duchowni czy też świeccy, ubrani w maski, nie wchodzili zuchwale do kościołów lub na przyległe cmentarze, zwłaszcza gdy się w nich odprawia służbę bożą" (Codex 1878, s. 395; Kolankiewicz 2020, s. 297). Z dalszej części tekstu dowiadujemy się, że zarówno świeccy, jak i duchowni "tego rodzaju poczwarne i wstrętne maszkary” nosili w rękach (Codex 1878, s. 395) lub byli w nie przebrani (Gloger 1903, s. 427). Jeśli określenie „tego rodzaju” moglibyśmy odnieść do masek (co zdaje się wynikać z kontekstu wypowiedzi), to dostajemy wskazówkę, że niekoniecznie (a przynajmniej nie tylko) były one noszone na twarzach uczestników celebracji ${ }^{6}$.

Mimo wciąż podejmowanych przez Kościół prób wykorzenienia z polskiej tradycji zwyczajów okołobożonarodzeniowych w postaci „widowisk, których uczestnicy w maskach i w skórach zwierząt tańczyli w kościołach i na przykościelnych cmentarzach" (Bylina 2009, s. 98), zwierzęce maski/kostiumy nie dają spokoju duchownym jeszcze w XV i XVI stuleciu (Michał z Janowca 1981, s. 57; Mikołaj z Błonia 1519, fol. 62). Nie był to jednak problem, który obejmował wyłącznie obszar Polski. Próby usunięcia niezgodnych z liturgią chrześcijańską zwyczajów bożonarodzeniowo-noworocznych podejmowano także w innych zakątkach Europy, i to od najwcześniejszych faz średniowiecza, bowiem już z przełomu V i VI stulecia pochodzi kazanie De kalendis tanuariis, w którym Cezary, biskup Arles, gromi zwyczaje polegające na „odwracaniu porządku wszystkich rzeczy, okrywaniu się bezwstydnym szkaradzieństwem”. Co więcej, „w te dni nieszczęśni ludzie, a co gorsza, także niektórzy ochrzczeni, przybierają kształty nierządne, wygląd monstrualny

${ }^{6}$ Leszek Kolankiewicz (2020, s. 316) domyśla się tutaj zwyczaju chodzenia z kobylicą (gdzie indziej z kozą). Inaczej sprawę widział Jerzy Burchardt, który - podobnie jak niektórzy autorzy dziewiętnastowieczni (por. Berwiński 1862, s. 11-13) - uznał, że chodzi tutaj o „rytualne maski godowe” (Burchardt 1986, s. 38). 
[...] i przywdziewając strój zwierzęcy robią z siebie jelenia”. Natomiast „inni noszą bydlęce skóry, jeszcze inni biorą głowy zwierząt, ciesząc się i chełpiąc, że tak zmienili swój wygląd w zwierzęcy, że nie wyglądają na ludzi” (Olszewski 2002, s. 27). Pojawiają się tu, znane nam z ziem polskich, maski, stroje i figury zwierzęce oraz tańce/skoki mające naśladować zachowania niewłaściwe człowiekowi (por. Walter 2006, s. 63).

Tradycję noszenia masek (talamasca), przebierania się za zwierzęta oraz „niegodnych zabaw z niedźwiedziem" potępia ponad trzy stulecia późnej biskup francuskiego Reims Hinkmar. W postanowieniach synodu zwołanego w 852 r. znalazły się także zarzuty skierowane do stanu duchownego, którego przedstawiciele nie dość, że brali udział w stypach, to nie zabraniali „diabelstw” dokonywanych w maskach demonów (Kiersnowski 1990, s. 208; Schmitt 2006, s. 287; Walter 2006, s. 90). W zbliżonym tonie wypowiadał się w XII w. Wincenty z Beauvais, narzekając na podobne zwyczaje obecne w kościołach francuskich (Berwiński 1862, s. 12-13). Na Wyspach Brytyjskich analogiczne formy obrzędowości znane są przynajmniej od końca VII stulecia. Z tego bowiem okresu pochodzą wiadomości o piętnowanych przez Kościół tradycjach przebierania się w bydlęce skóry i używaniu wyobrażeń głów zwierzęcych podczas obchodów kalend styczniowych (Semple 1998, s. 212; Pollington 2011, s. 41) ${ }^{7}$.

Pamiętając o tym, co powiedzieliśmy, powróćmy jeszcze na moment do przekazu Kosmasa, gdyż dopiero teraz możemy zwrócić uwagę na inny szczegół jego opowieści. Brakuje w niej bowiem informacji o porze roku/cyklu obrzędowego, w której odbywały się relacjonowane wydarzenia. Co prawda treść przekazu wyraźnie sugeruje działania okołopogrzebowe, jednak „bezbożne igry i korowody odprawiane podług pogańskiego zwyczaju” żywo przypominają - jeśli można uprzedzić nieco dalszy tok rozważań - „zabobonne igraszki wedle karygodnych miejscowych zwyczajów” pełnych „rozpusty i obscenicznych gestów” (Kolankiewicz 2020, s. 316) oraz skoki, tańce i transformacje w dzikie zwierzęta, jakie znamy ze źródeł późniejszych. Czy w związku z tym - jeśli opisywane w Kronice Czechów korowody miały miejsce w okresie okołonoworocznym - należałoby je uznać za tożsame z tymi, które nieco później odbywały się w kościołach i leżących w ich cieniu cmentarzach? Nie można tego definitywnie wykluczyć, choć ze względu na miejsce wydarzeń rozgrywanych poza ekumeną - w świecie nieoswojonym, wydaje mi się to mniej prawdopodobne.

Podobne wątpliwości pojawiają się w dyskusji nad jednym z fragmentów De ceremoniis aluae Byzantinae autorstwa cesarza bizantyńskiego Konstantyna Porfirogenety (905-959). Mowa w nim o obrzędowym tańcu określonym jako gothikon, który wykonywali mężczyźni przyodziani w maski oraz ukryci pod zwierzęcymi skórami noszonymi futrem na zewnątrz. W literaturze przedmiotu utrwaliło się przekonanie, że byli nimi warescy (ruscy) najemnicy przebywający w służbie władcy Bizancjum, sam zaś taniec należy wywodzić ze sfery wyobrażeń ludów skandynawskich i uznać za rytuał właściwy związkom wojowników. Pojawiła się jednak alternatywna propo-

${ }^{7}$ Możliwe, że tradycja ta sięga czasów rzymskich, kiedy kalendy styczniowe celebrowano widowiskami z tańcami oraz ofiarą z byka składaną Jowiszowi. 
zycja, wedle której opisywany zwyczaj znany był na dworze bizantyńskim znacznie wcześniej, bo od VI w. I nawet, jeśli został przyniesiony przez Gotów (co zdradza nazwa), to zaadaptowany, wkrótce stał się częścią lokalnej tradycji (por. Price 2002, s. 370-371; Bregenhøj 2012, s. 113; Gunnell 2012, s. 188). W takim ujęciu uwagę zwraca czas opisywanych wydarzeń, który przypadł na dziewiąty dzień Bożego Narodzenia. Zresztą obie propozycje mogą się wzajemne uzupełniać, gdyż jeśli dla Waregów taniec w maskach/futrach, z uzbrojeniem i okrzykami rzeczywiście był jakąś formą rytuału, to dla biorących udział w relacjonowanych wydarzeniach chrześcijan mógł nieść zupełnie inne treści wiązane z obchodami świąt.

Na koniec tej części rozważań przywołajmy jeszcze jeden zapis, tym razem bezpośrednio związany ze Skandynawami. Rzecz dzieje się w IX w. i dotyczy Rollona, znanego też jako Hrólf Wędrowiec. Nie będą nas jednak zajmować losy duńskiego wikinga. Na marginesie dociekań pozostać też musi wiarygodność informacji przekazanych przez Göngu-Hrólf saga. Dla nas przekaz ten jest istotny ze względu na pojawiające się $\mathrm{w}$ nim postaci $\mathrm{z}$ twarzami zakrytymi maskami, przede wszystkim zaś na informację, że te ostatnie były zakapturzone, co może zdradzać sposób, w jaki były mocowane do twarzy. Nie bez znaczenia pozostaje i to, że przytoczony fragment bywa przywoływany w studiach nad słynnymi maskami z Hedeby (np. Bregenhøj 2012, s. 111), do których za moment wrócimy.

Na razie spróbujmy podsumować to, co możemy powiedzieć na temat funkcji takich przedmiotów w obrzędowości (nie tylko) Słowian na podstawie przekazów pisanych. Analiza ich treści skłania do wniosku, że mamy do czynienia z informacjami relacjonującymi dwa odrębne jakościowo zjawiska kulturowe. Trudno byłoby bowiem postawić znak równości między wydarzeniami przywołanymi przez Kosmasa a zapisami potępiającymi „diabelskie/niegodne zabawy” w kościołach i na cmentarzach. Pierwsze (do których - biorąc problem szerzej - należałoby może włączyć tańce wareskich najemników w Konstantynopolu) wydają się odwoływać do reaktualizacji wydarzeń mitycznych. Opierając się na studiach Gerardusa van der Leeuwa (1978, s. 421), moglibyśmy określić je jako inscenizacje kultowe. W takim ujęciu „aktorzy” odgrywaliby role bogów, innych postaci nadprzyrodzonych lub/i duchów/przodków/herosów. „Tylko tak staje się zrozumiałe, dlaczego kostium i maska są niezbędne w czynności kultowej. W tańcach z maskami [...] tancerze w dosłownym sensie reprezentują demony czy bogów i wydarzenie, które się dokonało, tzn. ponownie przedstawiają tamto wydarzenie, znów je uobecniają; oni s ą duchami lub demonami, a wydarzenie znów zachodzi" (van der Leeuw 1978, s. 421; por. Porębska-Kubik, Marcinkowska 1992, s. 3; Aldhouse Green 2005, s. 169). Wiele zdaje się przemawiać za tym, że w przypadku przywołanych wyżej źródeł były to maski zoomorficzne (co, jak zaraz zobaczymy, znajduje niezłe potwierdzenie $\mathrm{w}$ analizie wątków ikonograficznych).

O wiele liczniejsze są zapisy źródłowe zogniskowane na tradycjach okołobożonarodzeniowych/noworocznych. Większe zainteresowanie piśmiennictwa średniowiecza właśnie tymi wydarzeniami wiązać należy z miejscem obchodów. Spisujący swoje relacje duchowni nie mogli pogodzić się z tym, że obrzędy - oparte przecież, jak sądzili, na wątkach dalekich liturgii chrześcijańskiej - odprawiano w murach 
świątyń i na przykościelnych cmentarzach. Przywoływane piórem ludzi Kościoła szczegóły skonfrontowane z późniejszymi zapisami pozwoliły na próbę rekonstrukcji przebiegu takich inscenizacji, w trakcie których „kobiety i mężczyźni schodzili się po domach, z łyka robili konie i tury, stroili się, na twarze nakładali maski zwierzęce, przywiązywali sobie ogony, obnażali wstydliwe części ciała i tak przy wtórze trąb, śpiewów i klaskania ruszali po ulicach miast i po wsiach [...] wykonując bezwstydne ruchy" (Kolankiewicz 2020, s. 316). Jeśli moglibyśmy podeprzeć się wynikami ustaleń etnografów, to treści symboliczne wszystkich tych czynności należałoby włączyć do praktyk obrzędowych podejmowanych w celu rewitalizacji uśpionych sił natury, pobudzenia witalności, urodzaju, a nade wszystko życia (np. Stelmachowska 2016, s. $286 \mathrm{nn}$.). Nie były to więc obrzędy związane ze śmiercią i przywoływaniem zmarłych. I nie ma tu większego znaczenia, że niektóre z postaci biorących udział w pochodach używały masek antropomorficznych, odgrywając rolę "gości z zaświatów” (Perszon 1999, s. 264). Natomiast nieco inne znaczenia kultura ludowa nadawała maskom zoomorficznym. Noszące je osoby brały na siebie rolę duchów leśnych (na ogół wyobrażanych jako niedźwiedzie lub wilki), postaci mediacyjnych (niedźwiedź, koń) lub wiązanych z dobrobytem i urodzajem (koza, koń, bydło, bocian; Moszyński 1968, s. 278 nn.; Vulcãnescu 1979, s. 56; Korolenko 2006, s. 18; Stelmachowska 2016, s. 78). W związku z tym różne były też treści przypisywane tym wyobrażeniom - od apotropaicznych (chroniących przed dzikimi zwierzętami lub demonami), po rezurekcyjne (związane z pobudzaniem sił życiowych i wegetacji). Były to zatem działania o charakterze ściśle magicznym (Moszyński 1968, s. 286).

Zbliżone pod względem znaczeń zwyczaje i wierzenia notujemy na obszarze całej Europy, i to przynajmniej od najwcześniejszych faz średniowiecza. Jednocześnie, pozostając jeszcze przy literze źródeł, warto odnotować próby przewartościowania ukrytych w maskach treści oraz włączenia ich do tradycji chrześcijańskiej. W nowej rzeczywistości wkrótce stały się one rekwizytami wykorzystywanymi w zwyczajach związanych ze św. Mikołajem, obchodami Trzech Króli czy zapustami (Maertens 2010, s. 711). Widzimy je również podczas obchodów święta głupców, w którym „wszyscy duchowni brali [...] udział z umazaną na czarno twarzą albo w okropnych i śmiesznych maskach" (Duluare 2009, s. 274). To z kolei prowokuje ważne dla nas pytanie: „ile tradycji zostało w tradycji?”, a stawiając problem inaczej: w jak dużym stopniu odprawiane w kościołach inscenizacje w maskach zachowały przedchrześcijański charakter i czy w taki właśnie sposób świadomie postrzegali je biorący w nich udział księża?

\section{MASKA W IKONORAFII}

Korpus słowiańskich zabytków, na których zachowały się wyobrażenia postaci noszące (lub mogące nosić) maskę jest niezwykle ubogi i w wielu przypadkach dyskusyjny. Pierwszym, który w kontekście podjętych tu problemów przykuwa uwagę, jest kabłączek skroniowy odnaleziony w 1886 r. w miejscowości Turza (Horst) na 


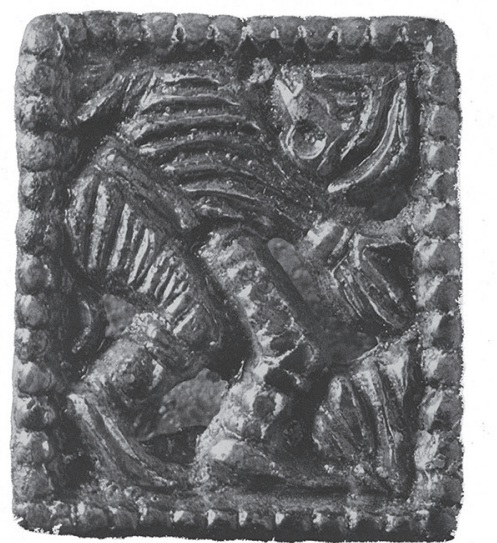

a

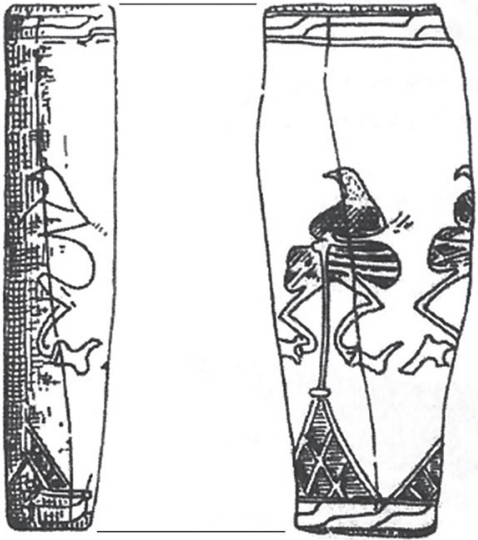

b
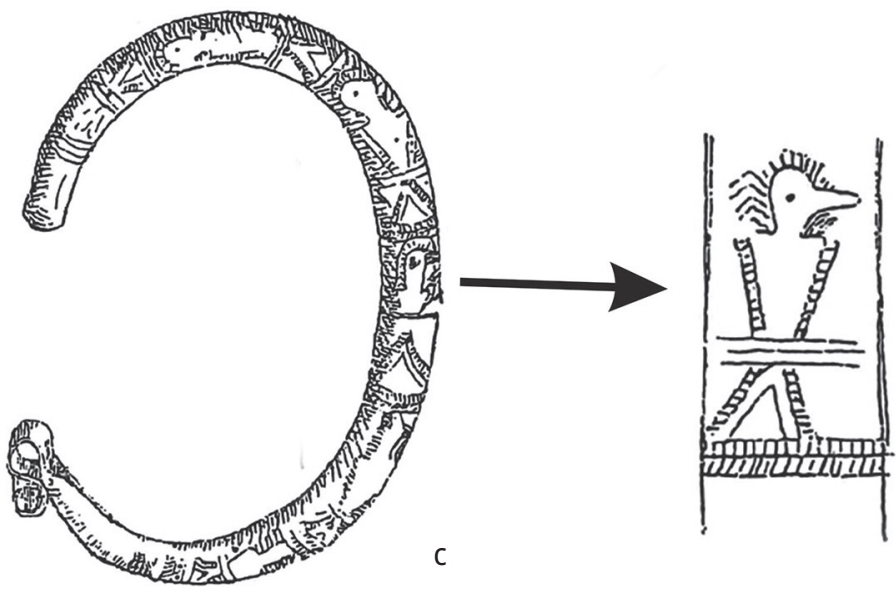

0

$6 \mathrm{~cm}$

Ryc. 5. Przedmioty z wyobrażeniami postaci noszących maski

a - Hraničná nad Hornádom, przewleczka pasa z postacią antropomorficzną; b - Wolin, drewniana rękojeść z wizerunkiem postaci tzw. tanecznicy; c - Turza, kabłączek skroniowy z wizerunkami antropomorficznymi.

Wg Dekana 1979, ryc. 64, bez skali (a); Stanisławskiego 2013b, ryc. 17, bez skali (b); Łęgi 1929, tabl. 38: 150a-b (c)

Fig. 5. Artifacts with representations of figures wearing masks

a - Hraničná pri Hornáde, belt buckle with a depiction of an anthropomorphic figure; b - Wolin, wooden handle with the image of a so-called dancer; c - Turza, temple ring with an anthropomorphic representation.

After Dekan 1979, Fig. 64, no scale (a); Stanisławski 2013b, Fig. 17, no scale (b); Łęga 1929, Pl. 38: 150a-b (c) 
Pomorzu Zachodnim (ryc. 5c). Ozdoba wchodziła w skład tzw. skarbu datowanego na połowę XI stulecia (Lissauer 1892, s. 475; Schumann 1897, s. 96; Dorka 1939, s. 142; Bukowski 1960, s. 34) $)^{8}$. Pokryto ją ornamentem zwielokrotnionej postaci, którą w literaturze określa się jako zwierzęcą bądź ludzką, przy czym w pierwszej propozycji wskazuje się na ptaka lub rybę (Bukowski 1960, s. 34). Wyraźnie zaznaczony dziób i pióra (Łęga 1929, s. 279) skłaniają raczej do akceptacji pierwszej z postawionych hipotez. Nie ma natomiast większych rozbieżności w interpretacji dolnej części postaci, zgodnie opisywanej w literaturze jako ludzka. Jak dotąd, wedle mojej wiedzy, jedynie Witold Hensel oraz Normen Posselt i Paweł Szczepanik podjęli się próby odczytania treści przekazu zamieszczonego na kabłączku. I jeśli pierwszy ze wspomnianych autorów widzi tutaj „ryt narracyjny przedstawiający scenę obrzędową w rodzaju dochowanych do dziś pochodów z maszkaronami" (Hensel 1984, s. 118-119), to kolejni przyjęli, że na zabytku ukazano postać łączącą cechy ptaka, człowieka i (bliżej niesprecyzowanej) istoty (jak można się domyślać mitycznej). Tym samym przychylili się do propozycji badaczy kultur pradziejowych, którzy pojawiające się na dawniejszych przedmiotach wyobrażenia ornito-antropomorficzne uważają za ludzi ujętych w momencie przejścia do krain zaświatowych. Byłaby to zatem forma pośrednia ukazująca chwilę opuszczenia ciała przez duszę zmarłego (Posselt, Szczepanik 2017, s. 197-198). Nie można jednak wykluczyć i takiej możliwości, że na kabłączku pokazano człowieka lub ludzi ubranych w maski podczas realizacji jakiegoś scenariusza obrzędowego. Przypomnijmy, że duchy zmarłych w zachodniosłowiańskich wyobrażeniach eschatologicznych mogły być wyobrażane w formach zoomorficznych (najpewniej bydła i/lub ptaków). Stąd też, łącząc dotychczasowe spostrzeżenia, warto raz jeszcze wrócić do opisu, jaki zostawił nam Kosmas. Innym tropem mogłyby być, jak wkrótce się przekonamy, inicjacyjne ryty przejścia suponowane w przypadku niektórych zabytków ikonograficznych północnej Europy lub identyfikacja z jakąś postacią nadprzyrodzoną.

Zbliżony tor interpretacji pojawił się przy próbach rozszyfrowania charakteru postaci wyrytej na drewnianej rękojeści z badań Starego Miasta na Wolinie (ryc. 5b). Sytuacja stratygraficzna zaobserwowana w wykopie pozwoliła datować ją na IX stulecie. W tym jednak przypadku ukazana figura ma dodatkowy atrybut, najczęściej identyfikowany jako laska/różdżka. Sposób jej ukazania skłonił badaczy do uznania jej za tańczącą postać z ptasią głową (Cetwiński, Derwich 1987, s. 227; Filipowiak 1988, s. 90) lub "tanecznicę - fantastycznego stwora z ptasim łbem” (Stanisławski 2013c, s. 23). W literaturze utrwaliło się przekonanie, że (głównie ze względu na dodatkowo znajdujący się na tym przedmiocie motyw plecionkowy) należy go wywodzić z tradycji sztuki skandynawskiej (Stanisławski 2013c, s. 23).

Niewykluczone, że postać przyodzianą w maskę wyobrażono na innym artefakcie odkrytym w tym samym ośrodku. Chodzi o fragment płytki/zawieszki z łupku grafitowego znaleziony na terenie Starego Miasta w poziomie osadniczym datowanym na XII w. (ryc. 6e). Przedmiot ten z obu stron zdobiony jest scenami figural-

${ }^{8}$ Wespół z kabłączkiem zdeponowano jeszcze 350 monet, 2 srebrne paciorki filigranowe, 4 paciorki z agatu, 1 paciorek szklany (Bukowski 1960, s. 34-35). 

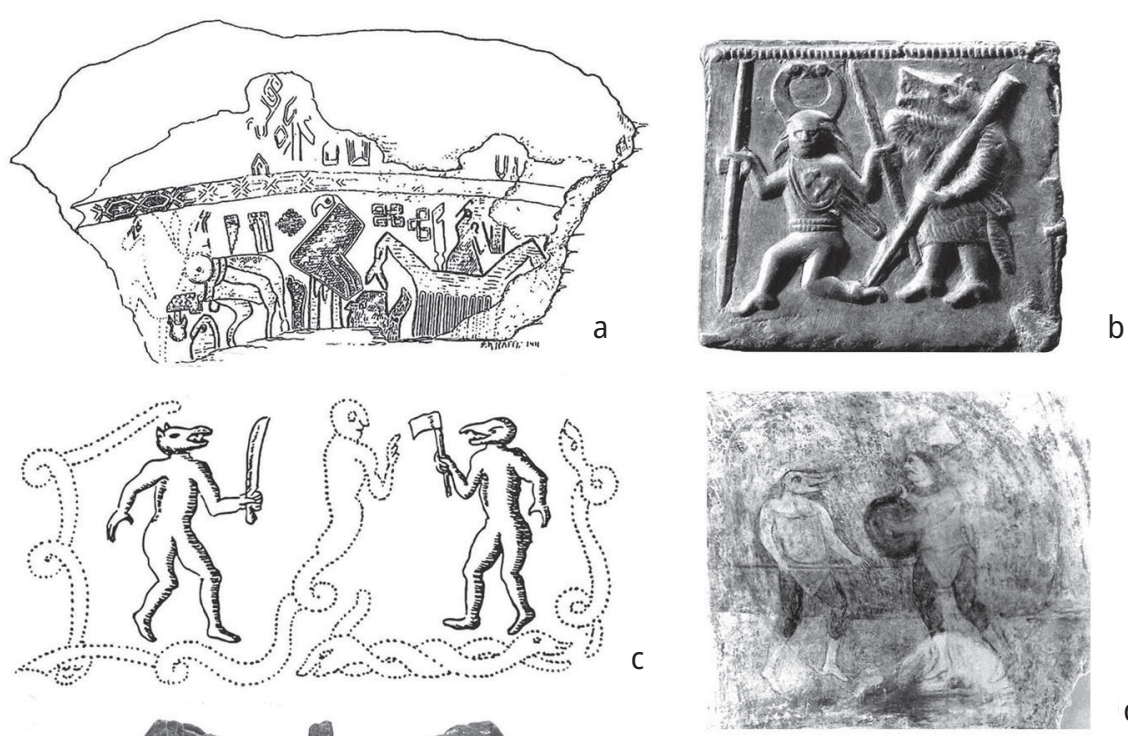

d
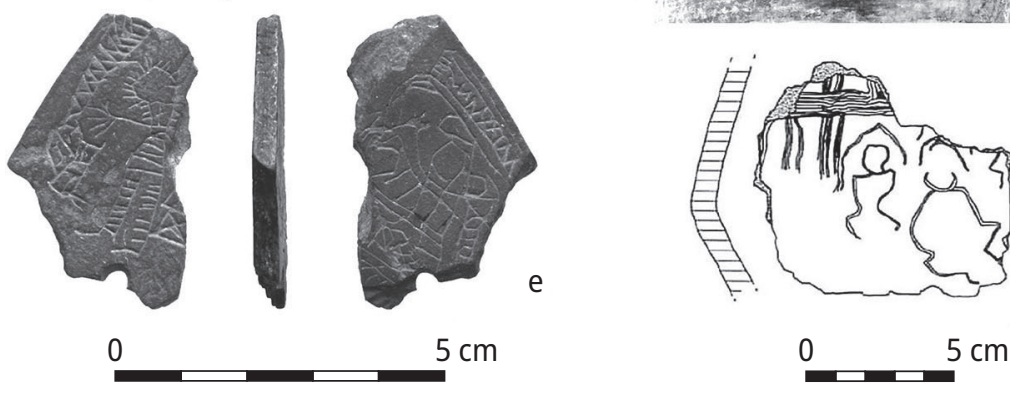

Ryc. 6. Przedmioty z wyobrażeniami postaci noszących maski a - fragment tkaniny z Oseberg z postaciami zoomorficznymi; b - płytka z Torslundy, Szwecja; c - zdobienie jednego z rogów z Gallehus, Dania; d - fresk na soborze św. Sofii w Kijowie, Ukraina; e - Wolin, fragment płytki z łupku z rytem narracyjnym; $\mathrm{f}$ - ryt na fragmencie naczynia $\mathrm{z}$ Repten, Niemcy.

Wg Gunnella 2012, ryc. 12-14; 18, bez skali (a-d);

Filipowiaka i Szydłowskiego 2019, ryc. 76 (e); Kinkeldeya 2008, ryc. 1b (f)

Fig. 6. Artifacts with representations of figures wearing masks

a - fragment of a textile with zoomorphic images, from Oseberg; b - plate from Torslund, Sweden; c - decoration of one of the horns from Gallehus, Denmark; d - frescoes from the Orthodox Church of St Sophia in Kiev, Ukraine; $\mathrm{e}$ - Wolin, fragment of a schist slab with a narrative engraving; $f$ - engraving on a fragment of a vessel from Repten, Germany.

After Gunnell 2012, Figs 12-14; 18, no scale (a-d); Filipowiak and Szydłowski 2019, Fig. 76 (e); Kinkeldey 2008, Fig. 1b (f)

nymi, z których pierwsza ukazuje jeźdźca wraz z innymi, choć trudnymi do identyfikacji, elementami figuralnymi. Na drugiej widać zarys wyobrażenia o cechach antropomorficznych z ręką i wyciągniętymi palcami skierowanymi ku kształtowi, 
który najczęściej charakteryzuje się jako postać węża/smoka. W opinii Władysława Filipowiaka (1993, s. 35) „scena sugeruje jakby walkę człowieka ze zwierzęciem”.

W dotychczasowych opracowaniach spotkać można dwie hipotezy odnoszące się do proweniencji tego zabytku i/lub umieszczonych na nim wątków narracyjnych. Według wspomnianego badacza, wskazującego dalsze „wężowe” wątki ornamentacyjne obecne w sztuce wczesnośredniowiecznych Słowian, należy ją wywodzić ze świata wyobrażeń południowego wybrzeża Bałtyku (Filipowiak 1993, s. 35-36). Błażej Stanisławski poszukuje jej już na Północy (Stanisławski 2013a, s. 188), choć - jak słusznie odnotowują Wojciech Filipowiak i Marcin Szydłowski - nie podpiera swojej propozycji żadnymi konkretnymi dowodami (Filipowiak, Szydłowski 2019, s. 227$228)^{9}$. Pozostawiając na chwilę problem pochodzenia zajmującego nas zabytku, warto zwrócić uwagę na dalsze szczegóły pojawiające się w analizowanej scenie. Wątpliwości dotyczące interpretacji, wedle której widać na niej walkę ze smokiem, wzbudza brak broni w dłoni wyciągniętej ku postaci (?) umieszczonej naprzeciw - jak powinniśmy się domyślać - atakującego. Jednak tym, co w kontekście podjętych tu problemów przykuwa szczególną uwagę, jest sposób wymodelowania figury antropomorficznej. Biegnące wokól jej głowy linie wydają się bowiem ukazywać włosy ${ }^{10}$. Jeśli taki był rzeczywisty zamysł autora rytu, to owłosienie biegnące wokół głowy, twarzy oraz szyi może odzwierciedlać futro. W związku z tym zastanawiają też dalsze detale, takie jak kształt twarzy przypominający pysk zwierzęcia (przy łatwości, z jaką można było pokazać ludzkie cechy anatomiczne: nos, usta, uszy). Może więc postać ukazuje jakąś istotę nadprzyrodzoną, hybrydę lub człowieka w zwierzęcej masce/futrze?

Według Thomasa Kinkeldeya postaci w maskach mogą być wyobrażone na jednym z fragmentów naczynia ceramicznego, jaki odkryto w połabskim Repten (ryc. 6f). W umieszczonych tu figurach niemiecki archeolog dopatruje się tancerzy oraz towarzyszącego im zwierzęcia (najprawdopodobniej konia). Tym samym całą scenę interpretuje jako wizualizację czynności obrzędowych. Niemniej jednak sam zdaje sobie sprawę z dużej hipotetyczności zaproponowanego sposobu odczytania analizowanego wątku zdobniczego, wskazując alternatywną - choć równie dyskusyjną - identyfikację, wedle której kształty umieszczone tuż przed postaciami antropomorficznymi nie byłyby maskami, lecz podniesionymi w geście adoracji rękoma. Ostatecznie T. Kinkeldey słusznie stwierdza, że definitywne rozszyfrowanie ukrytych tu treści nie jest możliwe (Kinkeldey 2008, s. 498).

W omawianym kontekście warto zwrócić uwagę na wątek figuralny zdobiący wykonaną ze stopu miedzi przewleczkę do pasa odkrytą w miejscowości Hraničná

${ }^{9}$ Co nie przeszkadza autorom, by motyw łączyć z wątkiem walki legendarnego Sigurda ze smokiem (Fafnirem).

${ }^{10}$ Podobny sposób modelowania postaci widzimy na jednym z pierścieni typu Orszymowice z cmentarzyska w Lutomiersku. Co ciekawe, figura po przeciwległej stronie ukazanej sceny ma „włosy” skierowane do wnętrza głowy, co może sugerować odmienne treści ontologiczne nadawane obu przedstawieniom, a które można by ostrożnie łączyć ze sferą zwierzęcą i ludzką. Taki sposób odczytania treści sceny umieszczonej na pierścieniu znajduje ciekawe implikacje w kontekście prób odczytania kodu symbolicznego z innych przedmiotów odkrytych na tym stanowisku, przede wszystkim ostróg zoomorficznych (Gardeła, Kajkowski, Ratajczyk 2019). 
nad Hornádom (Czechy) (ryc. 5a). Co prawda Jan Dekan (1979, fot. 64) uznał ją za „bestię wyodrębnioną z większej kompozycji”, jednak sposób wyobrażenia postaci każe zadać pytanie, czy zamysłem twórcy nie było ukazanie „tancerza” z twarzą zakrytą maską? Niestety, i tej hipotezy na gruncie dostępnej dziś bazy źródłowej nie zdołamy rozstrzygnąć.

W związku z zagadnieniem zamaskowanych postaci pozostawać może również relief znajdujący się na północnej wieży wzniesionego w 1037 r. soboru św. Sofii w Kijowie. Ukazano na nim dwie postaci, z których jedna, trzymając topór i tarczę, wydaje się atakować drugą - uzbrojoną we włócznię lub kij (ryc. 6d). Właśnie ta druga wzbudza szczególne zainteresowanie, bowiem zamiast ludzkiej ma głowę zakończoną zwierzęcym pyskiem. Ukazana na ścianie świątyni scena bywa interpretowana jako pojedynek błaznów, w którym cechy zoomorficzne uzyskiwano poprzez założenie maski (por. Cetwiński, Derwich 1987, s. 116). Innych treści dopatrzyli się tu Marek Cetwiński i Marek Derwich, którzy omawiany wątek zinterpretowali jako „rytuał w akcji”. Człowiek noszący maskę - jak chcą wspomniani badacze, dzika - odgrywałby tu rolę istoty demoniczno-chtonicznej walczącej z bóstwem gromowładnym. W takim ujęciu byłaby to reaktualizacja słowiańskiego mitu kosmologicznego (Cetwiński, Derwich 1987, s. 116; Kajkowski 2017, s. 248). Interesujący nas w tym miejscu relief przykuł również uwagę badaczy kultury wczesnośredniowiecznej Skandynawii, którzy dopatrzyli się w nim podobieństw do znanego nam już przekazu Konstantyna Porfirogenety opisującego wojenny taniec wareskich najemników. Tym samym postaci ukazane na ścianie soboru miałyby odtwarzać gothikon, w którym figura $\mathrm{z}$ włócznią/kijem nosiła maskę (według Terrego Gunnella - w formie „bardzo niepraktycznego hełmu”) wilka lub ptaka (Price 2002, s. 372; Gunnell 2012, s. 188-189).

Dzierżące broń (lub inne akcesoria) postaci odziane w skóry zwierzęce zakrywające również twarz znane są z innych zabytków sztuki północnej Europy. Najczęściej przywoływanymi są datowane na $\mathrm{V}$ w. zaginione rogi z Gallehus (ryc. 6c), pochodząca z VI-VII stulecia płytka zdobiąca hełm ze szwedzkiej Torslundy (ryc. 6b), kamienie z Källby i duńskiego Moesgaard, czy w końcu dziewiątowieczna tkanina ze słynnego pochówku łodziowego z norweskiego Oseberg (ryc. 6a) (Price 2002, s. 160, 173-174; Gunnell 2012, s. 187-189). Na wszystkich tych zabytkach interesujące nas figury stanowią część większego programu narracyjnego, który zazwyczaj interpretuje się bądź jako czynności obrzędowe (pogrzebowe, inicjacyjne), bądź wyobrażenia ubranych w skóry zwierząt wojowników znajdujących się w transie bitewnym (berserkir/úlfheðnir) ${ }^{11}$.

Jeśli północnoeuropejskie źródła ikonograficzne, szczególnie w konfrontacji z przekazami pisanymi, dają dość szerokie pole interpretacji, to już stan badań nad zabytkami słowiańskimi pozostawia wiele do życzenia. Zachowane na nich wyobrażenia figuralne są kłopotliwe w identyfikacji, odczytaniu, a tym samym dalszych

${ }^{11}$ W niektórych przypadkach (np. tkanina z Oseberg) dopuszcza się również możliwość, że ukazane postaci o cechach zoomorficznych nie noszą masek, lecz mają umiejętność transformacji w zwierzę (shape-shifters in animal form; Price 2002, s. 173). 
studiach. Kolejne trudności wiążą się z miejscem pochodzenia przedmiotów, na których zachowały się zajmujące nas sceny.

Uwzględniając wszystkie te trudności, po analizie przywołanych wątków narracyjnych, możemy pokusić się o wyciągnięcie czterech zasadniczych wniosków dla podjętych dalej rozważań: 1. większość zamaskowanych postaci wydaje się „odgrywać"/brać udział w scenariuszu obrzędowym. Dalsze widoczne w ukazanych scenach narracyjnych rekwizyty wydają się sugerować, że były to rytuały o charakterze religijnym ${ }^{12} ; 2$. jednak nie możemy mieć pewności, czy zamiarem autora było „umieszczenie” w nich człowieka w masce, czy też zaznaczenie obecności istoty nadprzyrodzonej; 3 . wszystkie zasłony twarzy noszą cechy zoomorficzne; i w końcu 4. jeśli uznamy je za maski, to są to przedmioty trójwymiarowe.

\section{ODKRYCIA ARCHEOLOGICZNE}

Największy dotąd zbiór przedmiotów zinterpretowanych jako maski pochodzi z badań wykopaliskowych Nowogrodu Wielkiego (ryc. 7a-d). Dotychczasowe opracowania na temat tych znalezisk nie pozwalają oszacować dokładnej liczby odkrytych egzemplarzy, jednak kilkanaście publikowanych okazów zdaje się być wystarczającą bazą do kilku ważnych uogólnień.

Wiemy, że wszystkie wykonano z materiałów organicznych, a ściślej - ze skóry i tkanin. Korpus źródeł pozwolił wydzielić trzy zasadnicze typy masek, do których zaliczono okazy antropomorficzne, zoomorficzne oraz „mieszane”. Większość pozwalała na zakrycie całej twarzy, inne tylko części czoła i oczu (Ovčinnikova, Kopnina 2000). We wszystkich wycięto otwory na oczy, w znaczącej liczbie przypadków także na nos, pozostawiając skrawek skóry, który zakrywał go podczas noszenia maski. Niektóre z egzemplarzy antropomorficznych miały charakterystycznie obrobione otwory na usta z wyraźnie wyciętymi w skórze zębami, ukazując grymas uśmiechu. W kilku przypadkach zachowały się także ślady farby podkreślającej linie oczu lub ust oraz kolorowe (czerwone, pomarańczowe, żółte) aplikacje widoczne na różnych partiach masek. Wyjątkowo pod tym względem prezentuje się okaz, w którym „na czole” - za pomocą czerwonego barwnika - wymalowano koło z promieniście odchodzącymi żółtymi liniami. Wzór, zapewne słusznie, interpretowany jest jako wyobrażenie solarne (Ovčinnikova, Kopnina 2000, s. 133).

Długość/wysokość wszystkich opublikowanych dotąd masek wynosiła około $25 \mathrm{~cm}$, zaś szerokość mieściła się w przedziale między 20 a $24 \mathrm{~cm}$. Oznacza to, że (wyłączając oczywiście opaski na oczy) założone na głowę mogły zasłonić całą twarz. Szczegółem na ogół pomijanym w opracowaniach dotyczących funkcji masek w obrzędowości słowiańskiej są detale wykończenia części zabytków. Według Owczinnikowej i Kopniny $(2000$, s. 132, 133) należy je uznać za dowód mocowania

12 Taki sposób interpretacji jest możliwy również, jeżeli uwzględnimy zastrzeżenia, że rysy wskazujące na nienaturalność/nie-ludzkość nie były w istocie maskami, lecz po prostu elementem fizjonomii postaci biorących udział w czynnościach obrzędowych (por. Price 2002, s. 174; Lemm 2007). 


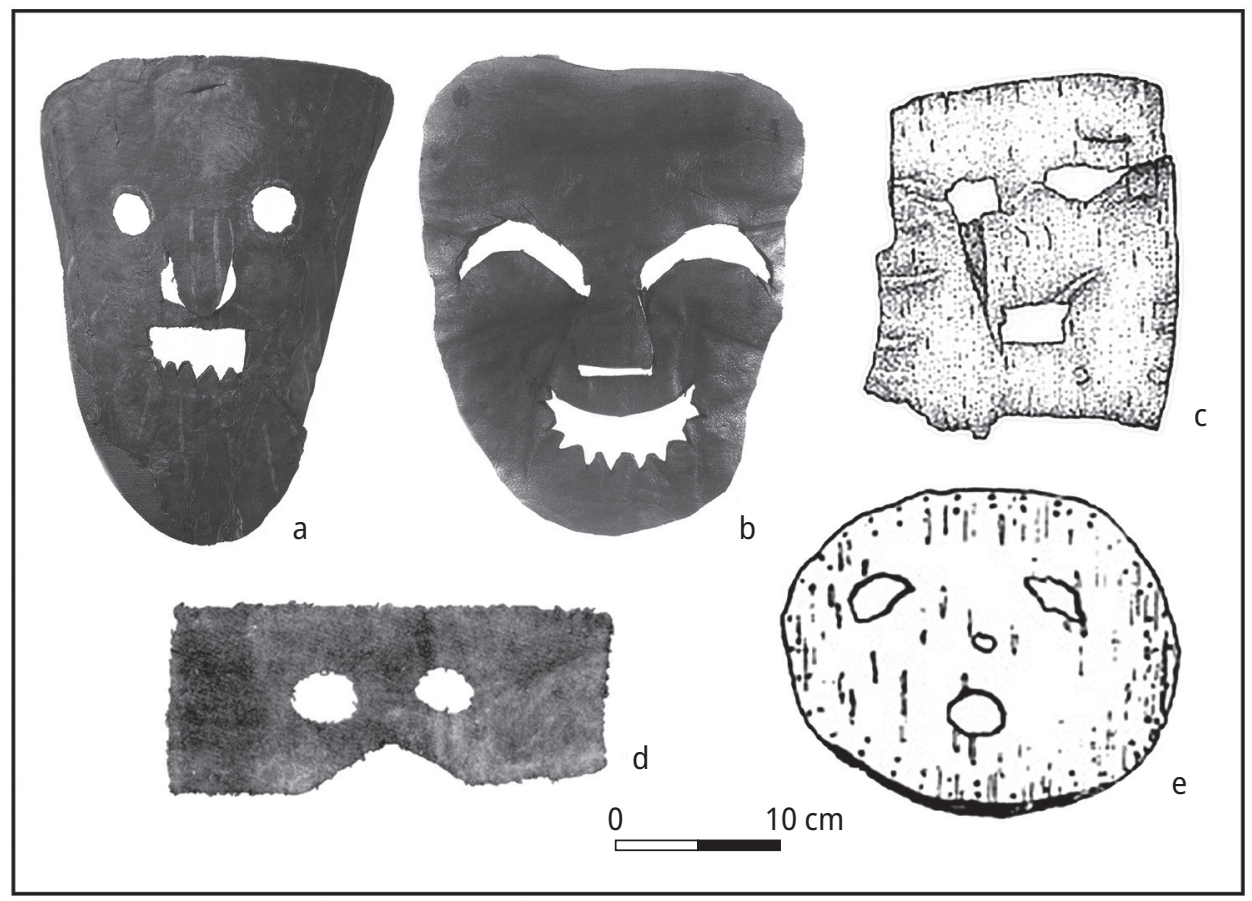

Ryc. 7. Maski skórzane z Nowogrodu Wielkiego (a-d) oraz maska z kory z Lukovca (e).

Wg Kolčina red. 1985, ryc. 27; 28 (a-b); www.historicaldis.ru, dostęp 11.09.2019 (c, d); Ovčinnikovej i Kopniny 2000, ryc. na s. 130 (e)

Fig. 7. Leather masks from Veliky Novgorod (a-d) and a birchbark mask from Lukovec (e).

After Kolčin ed. 1985, Fig. 27; 28 (a-b); www.historicaldis.ru, accessed 11.09.2019 (c, d); Ovčinnikova and Kopnina 2000, Figure on p. 130 (e)

do innych przedmiotów (kaptura? organicznych elementów „maszkar”?), co jednocześnie wskazuje, że nie musiały być noszone bezpośrednio na twarzy (inaczej Szczepanik 2020, s. 169).

Wszystkie maski z Nowogrodu Wielkiego pochodzą z nawarstwień obejmujących schyłek wczesnego i czasy późniejszego średniowiecza, a ściślej okres pomiędzy XII a XIV stuleciem (Ovčinnikova, Kopnina 2000, s. 130; Ovčinnikova 2013, s. 232$)^{13}$.

Do tej samej grupy znalezisk zalicza się maskę odkrytą na położonym w niewielkiej odległości od Nowogrodu grodzisku w Lukovcu (ryc. 7e). Jest to okaz wycięty

13 Wątpliwości do takiej chronologii zabytków podnosił Neil Price, wskazując na niedopatrzenia metodologiczne podczas prowadzonych dawniej w Nowogrodzie badań wykopaliskowych (Price 2002, s. 172). Niestety, nie sprecyzował, co dokładnie miał na myśli, każąc traktować je z pewną rezerwą. Trudno jednak oprzeć się wrażeniu, że zgłaszane zastrzeżenia są wynikiem rozbieżności dotyczących czasu użytkowania masek nowogrodzkich oraz tych znalezionych w Hedeby (o których niżej). 
w korze brzozy i datowany na koniec X - początek XI w. (Ovčinnikova, Kopnina 2000, ryc. na s. 130).

Zasadniczym pytaniem, jakie stawiają sobie badacze podejmujący wątek omawianych przedmiotów, jest funkcja, jaką mogły pełnić w życiu społeczności zamieszkującej średniowieczną Ruś. Jak dotąd nie udzielono na nie satysfakcjonującej odpowiedzi. Według Owczinnikowej i Kopniny (2000, s. 119) egzemplarze antropomorficzne wyobrażają ludzi lub istoty mityczne. Natomiast zwierzęcych nie można przyporządkować do konkretnego gatunku ${ }^{14}$. Autorki, rozważając rozmaite tropy (rekwizyty wołchwów/czarowników, akcesoria do nawiązywania kontaktów ze zmarłymi, wykorzystywane podczas tzw. święta niedźwiedzi bądź służące zwyczajom weselnym), ostatecznie skłaniają się ku obrzędowości bożonarodzeniowej/ noworocznej, nie wykluczając co prawda, że postać w masce mogła odgrywać rolę zmarłego. Jednak za bardziej prawdopodobny uznają ich udział w czynnościach o charakterze rezurekcyjnym - wedle scenariusza, w którym maska antropomorficzna służyła wizualizacji starego, mijającego roku czy (nie zawsze zaświatowego) przewodnika stada. W takim ujęciu byłaby ona częścią większego kostiumu, odgrywając znaczącą rolę w czynnościach pobudzających życie, witalność, ewokujących odrodzenie po odchodzącej zimie (Ovčinnikova, Kopnina 2000, zwłaszcza s. 130131; Ovčinnikova 2013, s. 229-230) ${ }^{15}$.

Potwierdzeniem domysłów rosyjskich badaczek wydaje się być dyspersja odnalezionych zabytków. Zarejestrowano je bowiem w różnych obszarach przestrzeni osadniczej, zapewne w związku z zabudową/infrastrukturą grodu. Zarówno to spostrzeżenie, jak i fakt, że nie zostały zdeponowane w większym zespole bądź wyróżniającym się („niezwykłym”) miejscu pozwalają wysnuć dwa ważne wnioski: 1. były to przedmioty utracone (zagubione) w różnych punktach osady, i 2 . nie były wykorzystywane w obrzędowości religijnej.

Dwa kolejne drewniane zabytki interpretowane jako maski odkryto w $1985 \mathrm{r}$. podczas badań archeologicznych wrocławskiego Ostrowa Tumskiego (ryc. 8a, b; por. Gediga 1996, s. 164, tam dalsza literatura). Znaleziono je w jamie pomiędzy dwoma budynkami (wykop III, warstwa C2, bliżej budynku 2), w odległości około 50-100 m od bryły katedry. Z tej samej warstwy pochodzi także bogaty zespół przedmiotów o różnym charakterze wykonanych ze skóry, drewna, kości, włosia oraz szczątki botaniczne, ponad 1100 fragmentów naczyń ceramicznych i 3590 kości zwierzęcych. Sytuacja stratygraficzna pozwoliła określić chronologię znalezisk na 3 ćwierć XI w. (Kaźmierczyk 1993, s. 75-79). Lakonicznej publikacji doczekał się tylko jeden z interesujących nas zabytków, który określony został jako maska. Przedmiot zachował się

${ }^{14}$ Choć nieco później próbują w nich widzieć wyobrażenia niedźwiedzia, kota, nawet lwa (Ovčinnikova, Kopnina 2000, s. 130; Ovčinnikova 2013, s. 227).

15 Tutaj też, być może, należałoby szukać wyjaśnienia grymasu pojawiającego się na kilku egzemplarzach. Cennym narzędziem może być w tym przypadku bachtinowska teoria karnawalizacji, z którą łączy się kultura śmiechu. Ten bowiem, wpisując się w radość Bożego Narodzenia, stawał się elementem świątecznej „dezorganizacji istniejącego ładu” i realizacji „świata na opak” (ostatnio Poraziński 2015, s. 8). Symbolizował przejście do świata obrzędu, w którym konstytuował pierwiastek ludzki, dynamiczny, żywy (por. Avierincev 1994, s. 87; Poraziński 2015, s. 9). 


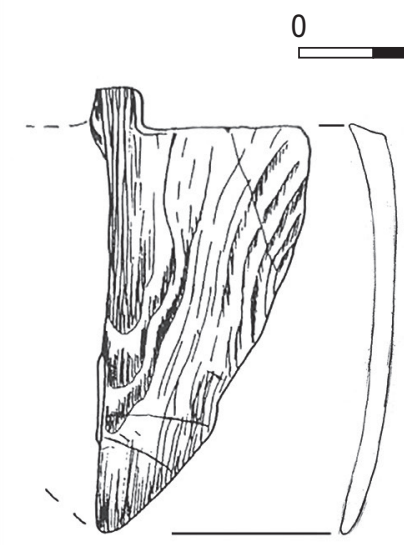

a

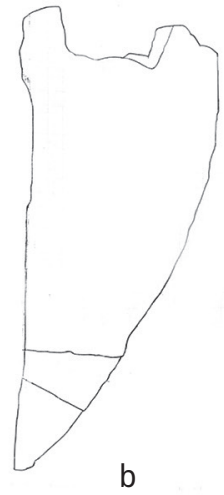

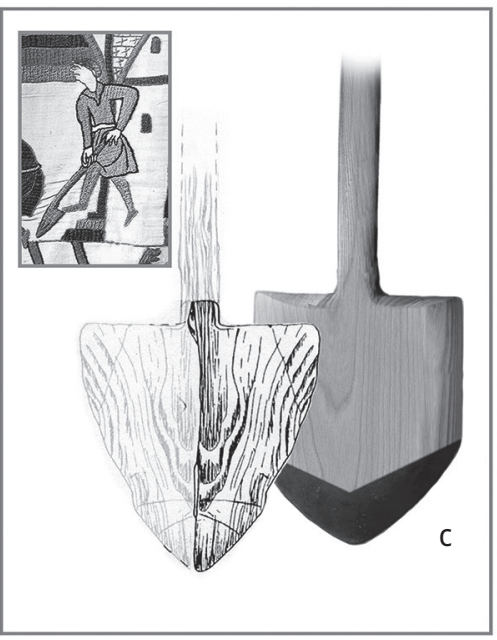

Ryc. 8. „Maski” z Wrocławia oraz próba ich reinterpretacji

a, b - Wrocław-Ostrów Tumski, zabytki zinterpretowane jako maski; c - graficzna propozycja interpretacji oraz replika wczesnośredniowiecznej łopaty i fragment tkaniny z Bayeux.

Wg archiwum Ośrodka Badań nad Kulturą Późnego Antyku i Wczesnego Średniowiecza IAE PAN we Wrocławiu (a, b); https://www.khanacademy.org/humanities/ap-art-history/early-europe-andcolonial-americas/medieval-europe-islamic-world/a/bayeux-tapestry, dostęp 20.12.2020 (c); opracował K. Szott

Fig. 8. "Masks" from Wrocław and an attempt to reinterpret them

a, b - Wrocław-Ostrów Tumski, artifacts interpreted as masks; c - graphic interpretation and replica of an early medieval spade and a fragment of the textile from Bayeux.

From the archives of the Centre of Research on Late Antique and Early Medieval Culture, Institute of Archaeology and Ethnology, Polish Academy of Sciences, Wrocław (a, b); https://

www.khanacademy.org/humanities/ap-art-history/early-europe-and-colonial-americas/ medieval-europe-islamic-world/a/bayeux-tapestry, accessed 20.12.2020 (c); processing by K. Szott

mniej w więcej w połowie. Według opisu z karty zabytku ${ }^{16}$, w szerszej części znajdowało się wygładzone wycięcie uznane za „część tworzącą [pierwotnie] oko”; w węższej (niewidoczne na rysunku ${ }^{17}$ ) wycięcie o kształcie „regularnego wycinka koła”. Na powierzchni zaobserwowano pozostałości obróbki oraz nieregularne nacięcia różnej długości biegnące ukośnie w stosunku do dłuższej osi. Podobnego kształtu, lecz nieco dłuższy i łukowato wygięty, jest drugi z odkrytych przedmiotów. Także $\mathrm{w}$ tym przypadku na karcie inwentarzowej odnotowano widoczne na powierzchni ślady obróbki. Stan zachowania zabytku pozwolił na konkluzję, że przetrwał w połowie. Warto też dodać, że z tej samej warstwy wydobyto dwie drewniane (bukową

${ }^{16}$ Karty inwentarzowe obu przedmiotów znajdują się w archiwum Instytutu Archeologii Uniwersytetu Wrocławskiego.

${ }^{17}$ Niestety, nie udało się dotrzeć do zabytków. Nigdy nie opublikowano też ich zdjęć. 

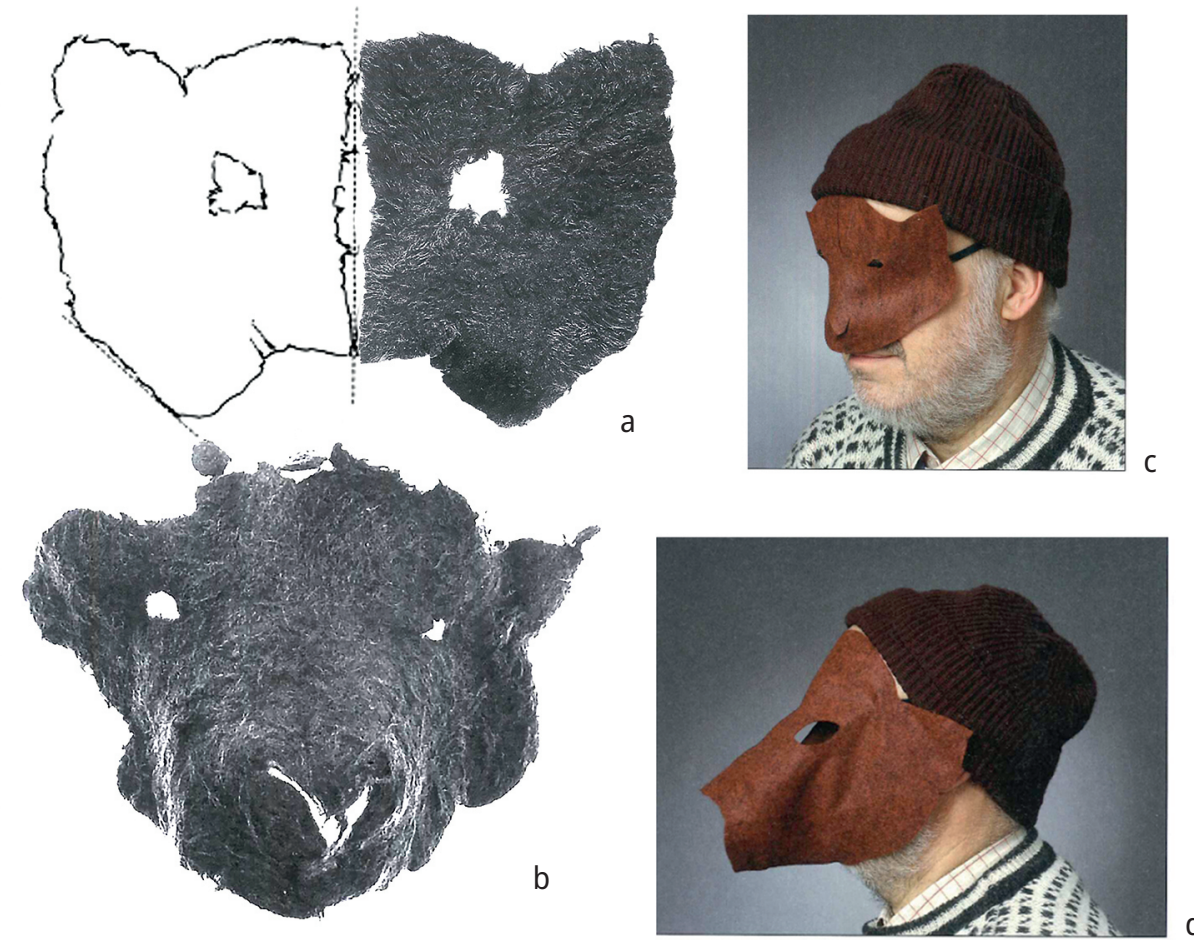

Ryc. 9. Hedeby, Niemcy. Maski tekstylne a - fragment 25 na tle graficznej rekonstrukcji zawierającej brakujący element; b - fragment 14D; c - rekonstrukcja maski 25; d - rekonstrukcja maski 14 .

Wg Bregenhøja 2012, ryc. 2 oraz Price’a 2002, ryc. 3.54 (a); Bregenhøja 2012, ryc. 1b; 3; 4 (b-d)

Fig. 9. Hedeby, Germany. Textile masks

a - fragment 25 overlaid on a graphic reconstruction including the missing element; b - fragment 14D; c - reconstruction of mask $25 ; \mathrm{d}$ - reconstruction of mask 14 .

After Bregenhøj 2012, Fig. 2 and Price 2002, Fig. 3.54 (a); Bregenhøj 2012, Fig. 1b; 3; 4 (b-d)

i dębową) figurki zoomorficzne określone jako koziołki (Kaźmierczyk 1993, s. 78). Wydaje się, że właśnie to ostatnie znalezisko, wsparte formalnym podobieństwem „masek” z Ostrowa Tumskiego do odkryć na Ostrówku w Opolu, legło u podstaw zbliżonych interpretacji funkcjonalnych. Niemniej jednak, zarówno kontekst wrocławskich odkryć, jak i cechy omawianych przedmiotów nie dają podstaw do uznania ich za maski, wskazując raczej na utylitarny zakres ich użytkowania. Niewykluczone, że przynajmniej jeden $\mathrm{z}$ nich stanowi destrukt łopaty (ryc. 8c).

Ostatnie już dostępne analizie zabytki archeologiczne pochodzą z obszaru wczesnośredniowiecznej Danii (dziś znajdującego się na terenie Niemiec). Są to dwie teks- 
tylne maski zoomorficzne (ryc. 9a, b) znalezione w latach 1979-1980 podczas badań portu w centralnej części emporium w Haithabu/Hedeby. Obie, nasączone smołą, odkryto w szczelinach wypełniających poszycie łodzi datowanej na X stulecie (Hägg 1984, s. 69-72). Pierwsza (oznaczona jako fragment 14D), wykonana ze sztywnego filcu, identyfikowana jest najczęściej z pyskiem owcy, choć wskazywano też inne możliwości (Price 2002, s. 171; Bregenhøj 2012, s. 111). Zachowane rozmiary sugerują, że mogła być użytkowana przez osobę dorosłą, względnie młodocianą (Price 2002, s. 171). Drugi fragment (oznaczony nrem 25) wykonano z grubej i pierwotnie usztywnionej wełny o diagonalnym splocie. Według Ingi Hägg, zarówno walory metryczne, jak i wygląd (szczególnie widok z profilu) wskazują, że maska zakrywała całą głowę, natomiast pod względem odwzorowania gatunkowego mogła wyobrażać łeb cielaka, choć i w tym przypadku w literaturze pojawiły się alternatywne opinie dopatrujące się tu cech właściwych bykowi, krowie, niedźwiedziowi (Back Danielsson 2007, s. 136-137), bądź też w ogóle wykluczające możliwość obecności cech zoomorficznych (Bregenhøj 2012, s. 112-113). Za sugestiami wspomnianej badaczki, podpieranymi znanym nam już fragmentem Göngu-Hrólf saga, przyjęło się natomiast uważać, że pierwotnie noszono ją wespół z kapturem zakrywającym resztę głowy, do którego była przywiązana, przypięta lub przyszyta (Price 2002, s. 171-172).

W literaturze przeważa pogląd, że zabytki z Hedeby, wtórnie użyte do uszczelnienia łodzi, wcześniej pełniły funkcję ekwipunku ochronnego (Hägg 1984, s. 220; Price 2002, s. 172). Przeciwnicy tej opinii wskazują na brak przesłanek dowodzących, że maski o takim przeznaczeniu miałyby przybierać formę zoomorficzną. Taką - jak sądzą - należałoby łączyć z chęcią ukazania „bestii” lub momentu transformacji w taką istotę nadprzyrodzoną (Bregenhøj 2012, s. 112). W obu propozycjach zwraca się uwagę na (podniesiony już przez I. Hägg) związek tych przedmiotów ze specyficzną grupą wojowników określaną w źródłach jako berserkir lub ulfheðnar (Price 2002, s. 172).

Zabytki pozyskane podczas badań archeologicznych w Nowogrodzie Wielkim, Lukovcu, Opolu, Wrocławiu i Hedeby, według mojej wiedzy, zamykają listę wczesnośredniowiecznych przedmiotów interpretowanych jako maski odkrytych na terenie europejskiego barbaricum ${ }^{18}$. To, co zdołaliśmy wywnioskować $\mathrm{z}$ analizy kontekstu wszystkich znalezisk, jak również cech zachowanych zabytków, można sprowadzić do kilku konkluzji: 1 . żaden nie został odkryty w miejscu, które sugerowałoby związek z religią/kultem; 2 . mimo że zarejestrowano zarówno egzemplarze antropo-, jak i zoomorficzne, procentowo większy udział należy przyznać maskom

${ }^{18}$ Na marginesie warto tutaj jeszcze przywołać znalezisko z Wielkiego Pałacu w Konstantynopolu. Odkryto tu depozyt militariów, w którym znalazło się dziewięć fragmentów antropomorficznych żelaznych masek (Brett, Macaulay, Stevenson 1947). Najczęściej uważa się, że były to przedmioty mające chronić twarz żołnierza przed ogniem greckim lub stanowić wyposażenie ciężkiej jazdy bizantyjskiej lub kumańskich najemników. Dla nas interesująca (choć podparta słabą argumentacją) może być opinia wyrażona przez Alexa Pluskowskiego i Philippę Patrick (2003), wedle których przedmioty te mogły służyć, znanym ze źródeł pisanych, odgrywanym w tym miejscu chrześcijańskim, acz nawiązującym do pogańskich zwyczajów „maskaradom” z udziałem kleru. 
zwierzęcym (do których jestem skłonny zaliczyć również egzemplarze „mieszane”); 3. ponieważ nie dysponujemy informacjami pozwalającymi uznać je za intencjonalne depozyty, należy przyjąć, że - poza wtórnie wykorzystanymi egzemplarzami z Hedeby - zostały zagubione lub wyrzucone; 4 . na podstawie dostępnych materiałów nie jesteśmy w stanie przekonująco określić ich pierwotnego przeznaczenia; 5. przy próbach interpretacji funkcjonalnej najczęściej wskazuje się (choć nie zawsze wprost) ich związek z obrzędowością magiczną.

Wszystkie te ustalenia, skonfrontowane z wcześniejszymi analizami, skłaniają do podtrzymania wniosku o rysującym się podziale masek na okazy, które mogły być wykorzystywane w czynnościach związanych z kultem oraz takie, których używano w obrzędowych działaniach o charakterze magicznym.

Uzbrojeni w całą zdobytą do tej pory wiedzę możemy teraz wrócić do odkryć z opolskiego Ostrówka. Poczynając od wskazania niekonsekwencji w argumentacji H. Cehak-Hołubowiczowej, raz jeszcze przyjrzymy się miejscu odkryć, detalom wykonania, wyglądowi, ergonomii oraz domniemanej roli zabytków, by na koniec podjąć ostateczną próbę odpowiedzi na pytanie: czy w Opolu odkryto maski obrzędowe?

\section{CZY W OPOLU ODKRYTO RELIKTY MASEK OBRZĘDOWYCH?}

Wyartykułowana przez wspomnianą badaczkę hipoteza zakłada, że odnalezione na Ostrówku przedmioty są reliktami masek obrzędowych wykorzystywanych podczas bożonarodzeniowego, zapustnego chodzenia z kozłem (Cehak-Hołubowiczowa 1965, s. 316). Podstawą takiej interpretacji, jak pamiętamy, były cechy antropomorficzne, jakich uczona dopatrzyła się na obu przedmiotach, kontekst ich zalegania, występujące w nim drewniane figurki określone jako koziołki oraz ustalenia etnografów opisujących obecne jeszcze pod koniec XIX w. (czy nawet na początku XX w.) zwyczaje kolędowe.

Pierwsze wątpliwości pojawiają się już na etapie opisu okoliczności odkryć: starszego $\mathrm{w}$ warstwie śmietniskowej pod legarami drewnianej ulicy, młodszego w narożniku budynku. Oba zdeponowano więc w niewyróżniającej się niczym nadzwyczajnym przestrzeni użytkowej badanej części osiedla. Niestety, w swoim opracowaniu H. Cehak-Hołubowiczowa nie wyjaśnia, dlaczego przedmioty, które łączy z wyjątkową (bo obrzędową) sferą życia dawnych mieszkańców Ostrówka, zostały wyrzucone. Nie tłumaczy też, dlaczego w tym samym kontekście stratygraficznym zalegały inne, „zwyczajne” przedmioty. I w końcu, skoro obecność drewnianego koziołka stała się ważkim argumentem w proponowanych interpretacjach, jak tłumaczyć fakt, że jednej „masce” taka figurka towarzyszyła, a w przypadku drugiej już jej nie było? Zresztą sama kwestia korelacji zaprezentowanych odkryć nie jest tak oczywista, jak to wynika z przytoczonego opisu. Według przechowywanej w archiwum Ośrodka Badań nad Kulturą Późnego Antyku i Wczesnego Średniowiecza Instytutu Archeologii i Etnologii PAN we Wrocławiu karty inwentarzowej, sytuacja stratygraficzna prezentowała się nieco inaczej. Płozę sań zarejestrowano 
na arze $342 \mathrm{w}$ warstwie $\mathrm{A} / 5$ na metrze $4 \mathrm{~b}$, podczas gdy „maska” znajdowała się co prawda na tym samym arze, ale $\mathrm{w}$ warstwie A/6 na metrze $4 \mathrm{~h}$. Trudno tu więc mówić o wspólnym kontekście zalegania. Podobne wątpliwości pojawiają się w przypadku drugiej, „niewykończonej figurki koziołka”. Jeśli pierwszą (wraz z „maską”) wydobyto $\mathrm{z}$ ara 342 , warstwy $\mathrm{D} 2$, na metrze $5 \mathrm{~h}$, to omawiany zabytek zalegał już w zupełnie innymi miejscu (ar 342, warstwa E/2, metr 6g, dom 19).

Kolejny problem stanowi funkcja przypisywana samym koziołkom ${ }^{19}$. Zmierzyła się z nim zresztą i autorka, uznając je za przedmioty symbolicznie reprezentujące obecność człowieka przebranego za zwierzę. Figurka trzymana w ręku miałaby więc odgrywać rolę postaci fizycznie nieobecnej podczas czynności obrzędowych (Cehak-Hołubowiczowa 1965, s. 316-317). Taki sposób widzenia ma jednak zasadniczą lukę - pozostaje bez precedensu, a tym samym nie da się podeprzeć żadnym rodzajem źródeł. Należy go więc uznać za (mimo, że możliwy do akceptacji, to jednak tylko) domysł.

Dalsze uwagi wypada odnieść już bezpośrednio do zabytków („masek”), które ze względu na cechy metryczne uznano za dobrze dopasowane do ludzkiej twarzy. Zastanawia jednak, dlaczego pośród tak skrupulatnie wymienionych parametrów nie znalazła się ich waga? Jest to sprawa niesłychanie istotna w przypadku przedmiotu noszonego na twarzy. Na razie odnotujmy tylko problem, do którego wrócimy w odpowiednim miejscu.

Pozostając przy wspomnianym dopasowaniu, wypada zwrócić uwagę na rozłożenie akcentów fizjonomicznych. Już u samej badaczki niepokój wzbudził zbyt nisko położony otwór, który zinterpretowała jako usta. Szybko jednak rozwiązała problem, stwierdzając, że oba przedmioty podczas użytkowania miały w dolnej części doczepione organiczne dodatki imitujące brodę, jednocześnie dopuszczając możliwość obecności dalszych elementów w postaci doklejonych brwi, wąsów czy nawet plastycznie wymodelowanego nosa (co nie przeszkadzało wcześniejszej konstatacji, wedle której na starszej „masce” za wyobrażenie tej części twarzy uznała J-kształtną bruzdę, przebiegająca wzdłuż dłuższej osi zabytku; Cehak-Hołubowiczowa 1965, s. 316).

Żadnych wątpliwości badaczki nie wzbudził też odmienny dla obu „masek” sposób obróbki ich „wewnętrznej” powierzchni, gdzie w jednym przypadku została ona wygładzona, w drugim zaś śladów takiego zabiegu nie zaobserwowano. Czy w przypadku przedmiotów o identycznej funkcji nie powinny być zachowane szczegóły wpływające nie tylko na zakres użytkowania, ale także na estetykę? I ta ostatnia pozostawia tu wiele do życzenia, choć H. Cehak-Hołubowiczowa starała się zmniejszyć to odczucie, podkreślając pokrycie starszej „maski” czerwoną farbą, a niestaranność wykonania tłumacząc pośpiechem. Takie argumenty nie rozwiązują problemu, wykazując jedynie dalsze luki w argumentacji. Od razu należałoby bowiem

19 Tym bardziej, że cechy tych przedmiotów nie muszą być dystynktywne dla właśnie tego gatunku ssaka. Musimy jednak pamiętać, że taki, a nie inny sposób interpretacji zbudowano na podstawie wyglądu lepiej zachowanego tzw. koziołka lednickiego. Dziś wiemy, że należy go uznać za wyrób dziewiętnastowieczny (Wrzesiński 1989). 
zapytać, dlaczego śladów barwnika nie zaobserwowano na drugiej „masce”? Trudno też zrozumieć, dlaczego przedmioty, które miały być wykorzystywane w ważnych dla wspólnoty wydarzeniach realizowanych w określonych momentach rocznego cyklu obrzędowego, miałyby zostać przygotowane w pośpiechu, i dlaczego? A jeśli z jakiegoś powodu tak rzeczywiście było, to jak miał się do tego proces doklejania elementów organicznych i malowania, skoro obie czynności wymagały nie tylko czasu potrzebnego dla ich wykonania czy przygotowania barwnika, ale także, żeby wyschnąć? Innymi słowy - jak wyjaśnić staranne i czasochłonne dopracowanie przedmiotu robionego w pośpiechu?

Cały ten wątek prowadzi nas do kolejnego szczegółu dotyczącego opracowania "zewnętrznych" stron zabytków. O „nosie” widzianym z profilu mieliśmy - i jeszcze będziemy mieć - okazję mówić. W tym miejscu należy podjąć wątek młodszego z odkryć, w przypadku którego wzdłuż dłuższej osi biegnie wyżłobiona „kreska”. W opinii H. Cehak-Hołubowiczowej wykonano ją umyślnie w celu programowego podziału „maski” na dwie połowy. Niestety, w dalszej części rozważań badaczka nie podejmuje problemu i nie wyjaśnia, jaki powód miałby przyświecać nadaniu jej takiego wyglądu.

Naturalnym etapem procesu analitycznego, zwłaszcza w archeologii, jest stosowanie metody porównawczej. Problem z opolskimi znaleziskami polega na tym, że na co wskazuje sama autorka opracowania - bezpośrednich analogii nie mamy. Jeśli jednak uznamy w nich relikty masek, sytuacja wydaje się już nieco lepsza, otwierając pewien zakres możliwości. Nic więc dziwnego, że podparcia dla proponowanych rozwiązań $\mathrm{H}$. Cehak-Hołubowiczowa szukała w wynikach badań prowadzonych w Nowogrodzie Wielkim, porównując znaleziska z Ostrówka do pozyskanej tam drewnianej, jak uważała, maski antropomorficznej (Cehak-Hołubowiczowa 1965, s. 310). Kłopot w tym, że przywołany przez autorkę okaz to wyrób skórzany. Został także przygotowany ze znacznie większą dbałością o szczegóły oddające nie tylko wyraźnie nakreślone cechy ludzkiej fizjonomii, ale także emocje (uśmiech).

Jako dalsze analogie H. Cehak-Hołubowiczowa (1965, s. 311-312) wylicza głowę z Jankowa, rzeźbę z Behren-Lübchin oraz zwieńczenie laski (?) z Nowogrodu Wielkiego. Taki zestaw zabytków, łączonych z tradycyjnym systemem wierzeń, wzmocniony jeszcze podobnie interpretowanym zespołem odkryć z Ostrówka, posłużył do zaakcentowania pogańskiego charakteru domniemanych obrzędowych masek (Cehak-Hołubowiczowa 1965, s. 316).

Analizując całą argumentację H. Cehak-Hołubowiczowej nie sposób pozbyć się wrażenia, że zbudowano ją na dość luźnych skojarzeniach: zbliżonego kształtu do zarysu i fizjonomii ludzkiej twarzy, formalnym podobieństwie do rzeźby słowiańskiej, wystąpieniu jednej z „masek” w kontekście stratygraficznym z figurką „koziołka” oraz wynikami badań etnograficznych (zbudowanych głównie na autorytecie Kazimierza Moszyńskiego, sugerującego przedchrześcijańską genezę zwyczaju chodzenia z kozłem; Moszyński 1967, s. 292).

Według opublikowanego opisu sytuacja stratygraficzna obu opolskich odkryć nie daje podstaw, by wiązać je z obiektami archeologicznymi w postaci osobnej jamy, określonych elementów konstrukcyjnych budynków/traktów komunikacyjnych itd. 
(ryc. 2; 4) Obserwacja ta nie uszła uwadze kolejnych autorów, którzy starali się pogodzić śmietniskowy charakter miejsca znalezienia ${ }^{20} \mathrm{z}$ suponowaną im funkcją. Uznano więc, że jako przedmioty nacechowane mocą sacrum, po zakończeniu czynności obrzędowych mogły zostać rytualnie połamane i wyrzucone. Pozostaje zapytać: dlaczego taki sposób postępowania miał dotyczyć samych tylko masek, a już nie koziołków? Tym bardziej, że śladów intencjonalnych zniszczeń nie odnotowano na figurce zoomorficznej zalegającej w sąsiedztwie starszego z zabytków. Jest to kwestia o tyle istotna, że właśnie jej obecność stała się ważkim argumentem za obrzędową funkcją obu domniemanych masek.

Sam akt dewastacji przedmiotów zaopatrzonych w silne właściwości performatywne/mediacyjne znajduje niezłe potwierdzenie w źródłach. Dowiadujemy się z nich o maskach przygotowywanych i rytualnie niszczonych zaraz po zakończeniu czynności obrzędowych (Porębska-Kubik, Marcinkowska 1992, s. 7), bądź też o wielokrotnym ich wykorzystywaniu i chowaniu po zakończonych już celebracjach (Gunnell 2012, s. 190-191). Zarówno rytualna destrukcja, jak i ukrywanie masek w obrębie przestrzeni o specjalnych właściwościach wynikały z nadawania im treści wynikających z obecnych w nich mocy sprawczych, które nie wygasały po zaprzestaniu używania (Porębska-Kubik, Marcinkowska 1992, s. 7; Alcorta, Sosis 2005, s. 338; Hedeager 2011, s. 129; Kerényi 2010, s. 688; Gunnell 2012, s. 191). Analogiczne działania (nie tylko zresztą) we wczesnym średniowieczu podejmowano w stosunku do innych przedmiotów obdarzanych takimi właściwościami (militaria, „akcesoria” magiczne). Obserwacje archeologów wykazują, że deponowano je w symbolicznie nacechowanych miejscach, gdzie były gięte, łamane, kamienowane i/lub nadpalane (por. Grinsell 1961; Kurasiński 2011; Gardeła 2016, s. 215 nn.; Aannestad 2018). Kontekst odnalezienia właściwie wszystkich takich przedmiotów wykazuje okoliczności daleko wybiegające poza nawias tego, co zwykliśmy określać jako zwykłe, potoczne czy utylitarne. Nie były i nie mogły to być miejsca związane z codziennym życiem, gromadzenia odpadów produkcyjnych ani śmieci. Szczegóły wyglądu wskazują, że nie były to także przedmioty „wykonywane w pośpiechu”, co po raz ostatni już kieruje naszą uwagę na cechy wyglądu charakteryzujące „,maski” z Opola.

Na początek wróćmy do sposobu obróbki ciesielskiej obu przedmiotów. Jeśli mielibyśmy zgodzić się z przypisywaną im funkcją, to jak rozumieć, że jedna z nich jest wygładzona od strony opisanej jako wewnętrzna, druga zaś od zewnętrznej? Jakie kryteria legły u podstaw określania, która strona przedmiotów jest zewnętrzna, która zaś nią nie jest? Czy był to sposób opracowania „oczodołów”, czy też punktem wyjścia były tutaj domniemany nos w przypadku większego okazu (a jeśli tak, to znowu - dlaczego nie widzimy go na drugim?) oraz lekkie zagięcie deski (kojarzące się z potrzebą „objęcia” czegoś) w przypadku młodszego egzemplarza? Na te pytania ani H. Cehak-Hołubowiczowa, ani kolejni autorzy nie dali odpowiedzi. Nie zwró-

${ }^{20}$ Biorąc pod uwagę całość interpretacji wyników omawianych tu badań na Ostrówku, pod znakiem zapytania można postawić również taki charakter omawianej warstwy. Niemniej jednak, analiza występujących w niej znalezisk sugeruje, że mamy do czynienia z reliktami miejsca i przedmiotów użytkowanych podczas codziennych zajęć. 
cili też uwagi, że ślady zachowane na zabytkach sugerują, iż przynajmniej niektóre z nich nie powstały podczas produkcji „masek”, lecz - jak chociażby wytarcia obecne w przekroju otworów - mogą być rezultatem wielokrotnego użytkowania, co tłumaczyłoby również, dlaczego w obu zabytkach odłamaniu uległa część najsłabsza, a więc najbardziej narażona na uszkodzenie podczas eksploatacji.

Kolejne zastrzeżenia wzbudza obecny na starszym zabytku detal, który stał się poważnym argumentem jego antropomorfizacji. Wracamy tutaj do przerwanego wcześniej wątku nosa widzianego z profilu. Już wstępny ogląd bruzdy mającej układać się w kształt tej części twarzy budzi wątpliwości. Nie jest to bowiem rezultat intencjonalnych działań człowieka, ale wynik procesów naturalnych, w tym przypadku ślad żeru (chodników) kornika. Podobny widać w innych miejscach, np. pod lewym „oczodołem” (ryc. 10) ${ }^{21}$. Można oczywiście przyjąć, że właśnie ten szczegół, budzący określone skojarzenia, mógł zaważyć na wyborze takiego, a nie innego fragmentu kory, jednak w kontekście znanych nam zachodniosłowiańskich wyobrażeń antropomorficznych i umieszczonych na nich szczegółach ludzkiej fizjonomii (por. niżej) wydaje się to mało prawdopodobne.

Dalsze wątpliwości wzbudza ewentualny sposób, w jaki „maski” miałyby być noszone, a ściślej przymocowane do głowy? Tym bardziej, że na zachowanych zabytkach nie widać żadnych rozwiązań mogących służyć temu celowi bądź służących doczepianiu do innego przedmiotu. Metoda obróbki zachowanych krawędzi wydaje się wręcz dowodzić, że takich rozwiązań pierwotnie tutaj nie uwzględniono. Pomni tych uwag, załóżmy na chwilę, że rzeczywiście mamy do czynienia z rekwizytami obrzędowymi służącymi do zakładania na twarz. Czy w takim wypadku byłyby to przedmioty o odpowiedniej ergonomii? W rozwiązaniu tego problemu posłużą nam spostrzeżenia na temat użytkowania repliki przygotowanej według lepiej zachowanego okazu z badań grodu na Ostrówku. Pierwsze problemy wynikające z funkcjonalności maski pojawiły się już na etapie opracowania materiału, z którego została wycięta. Przypomnijmy, że oryginał wykonany został z deski sosnowej o grubości od 3,7 do 5,3 cm. I mimo, że w klasyfikacji gęstości drewna sosna uchodzi za gatunek lekki ${ }^{22}$, to tak określone parametry zabytku właściwie uniemożliwiają jeśli nie samo założenie, to na pewno stabilne utrzymanie się na twarzy. Aby usunąć problem, przygotowując kopię, trzeba było wybrać z wnętrza dość sporą partię materiału.

${ }^{21} \mathrm{Na}$ marginesie warto tutaj wskazać jeszcze jeden trop, choć - co trzeba podkreślić - wymagający dalszych szczegółowych studiów. Jeśli bowiem wiemy, że zaatakowane i zasiedlone przez te szkodniki drzewo zamiera w ciągu 3-4 miesięcy, to możemy z dużą pewnością przyjąć, że omawiany przedmiot wykonano z drewna martwej sosny. Oznacza to, że nie miał już pożądanych dla działań obrzędowych cech symbolicznych łączących ambiwalencję Natury. Żywe drzewo, reagując na zmieniające się pory roku, kodowało kulturowo-symboliczne znaczenia wiązane z odradzaniem i życiem, dlatego przedmioty wykonane $\mathrm{z}$ takiego surowca najlepiej nadawały się do działań o charakterze magicznym (Aldhouse Green 2005, s. 96; Słupecki 2016). Obumarłe drzewo nie mogło służyć do tworzenia rekwizytów służących pobudzaniu sił witalnych, choć mogło służyć wykonywaniu rekwizytów odwołujących się do śmierci.

${ }^{22}$ Natomiast brzoza, z której wycięto - jak pamiętamy - drugi egzemplarz, widnieje w tej skali w przedziale gatunków umiarkowanie ciężkich (www.encyklopedia.lasypolskie.pl/doku.php; dostęp: 16.11.2020 r.). 


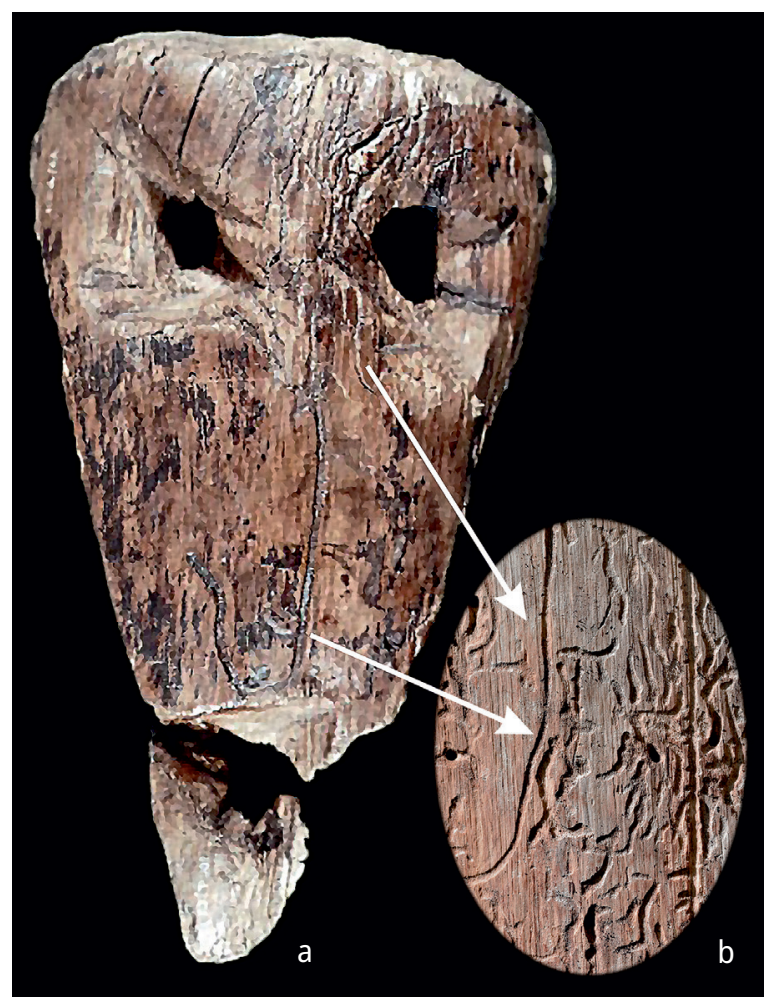

Ryc. 10. Korytarze kornika na starszej tzw. masce z Opola (a) oraz współczesnym drzewie (b).

Opracował K. Szott

Fig. 10. Bark beetle corridors on the older so-called mask from Opole (a) and a modern tree (b).

Processing by K. Szott

Zmniejszając grubość, udało się otrzymać efekt pozwalający nieco lepiej dopasować ją do twarzy i o blisko 1/4 obniżyć ciężar. Niezbędnym elementem było wyposażenie maski w mechanizm mocujący, za który posłużył skórzany pasek przynitowany od wewnętrznej strony, na wysokości dolnej linii otworów ocznych (ryc. 11). Mimo wszystkich tych zabiegów, założona na twarz maska, zamocowana za pomocą rzemienia, opiera się na czole i grzbiecie nosa, co, z jednej strony, mogłoby (szczególnie zimą) utrudniać oddychanie, z drugiej zaś, znacznie ogranicza pole widzenia, zmuszając do poruszania się z pochyloną głową. Jest to cecha szczególnie kłopotliwa, jeśli przypomnimy sobie treść źródeł wskazujących igry, tańce, korowody, zatem czynności wymagające dużej dynamiki motorycznej. W efekcie wykonana z oszlifowanej deski niemal płaska maska, trzymająca się jedynie na pasku/rzemieniu, jeśli nie spadnie z głowy, to przynajmniej zsunie się z otworów na oczy praktycznie oślepiając osobę noszącą ją na twarzy, a w rezultacie narazi ją na bardzo niepożądane i niebezpieczne skutki nieprawidłowego odegrania swojej roli w rytuale. Jest 


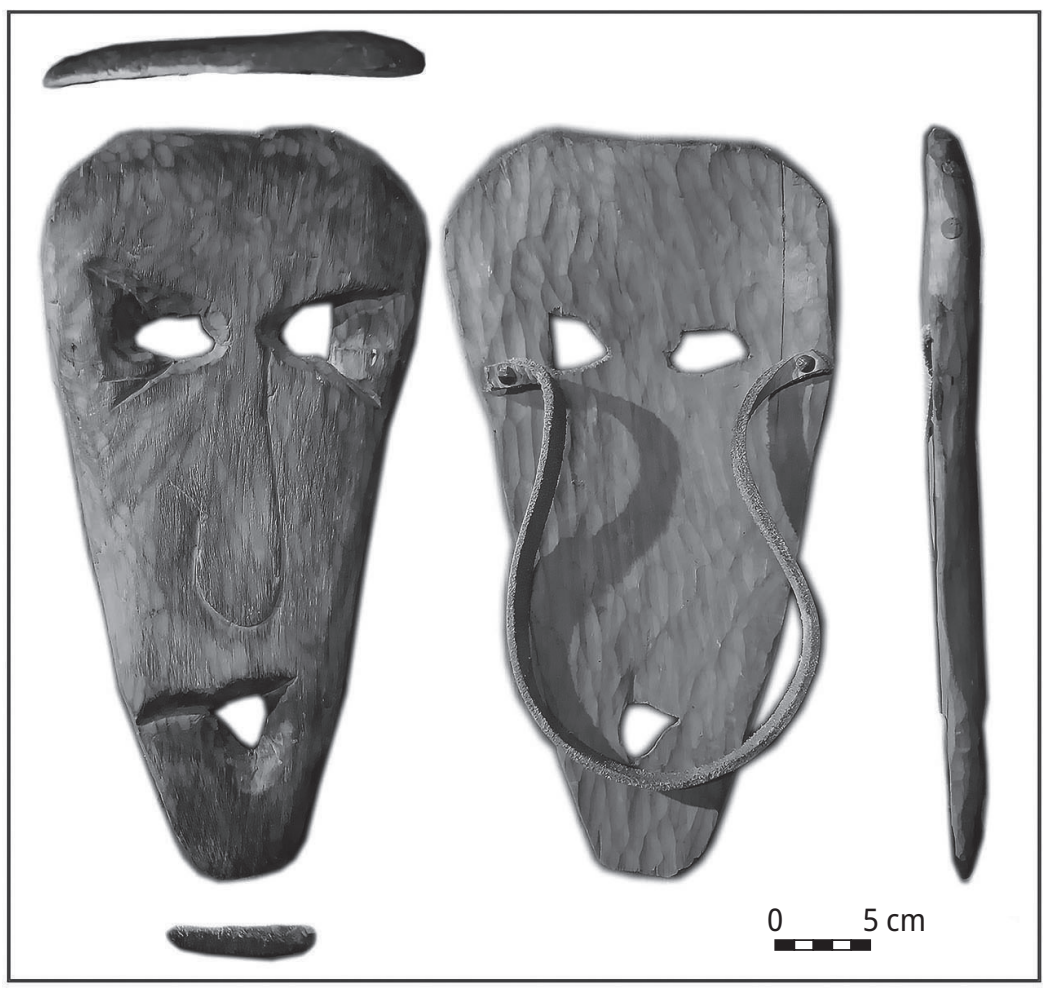

Ryc. 11. Kopia starszej tzw. maski z Opola.

Fot. S. Uta

Fig. 11. Copy of the older so-called mask from Opole.

to spostrzeżenie doskonale wyjaśniające dlaczego znane z wykopalisk maski zostały wykonane ze skóry lub tkaniny.

Zarówno cechy wyglądu tych ostatnich, jak również analiza detali widocznych na przedstawieniach ikonograficznych kierują uwagę na kolejny jeszcze szczegół charakteryzujący średniowieczne maski. Wszystkie bowiem są trójwymiarowe lub sprawiają wrażenie takich przedmiotów. Nie widzimy tego na zabytkach z Opola.

$\mathrm{Na}$ koniec poświęćmy jeszcze chwilę uwagi dociekaniom komparatywnym podejmowanym dla potwierdzenia już nie samej funkcji, ale sfery obyczajowości, w której były wykorzystywane. Na ogół bowiem, jako analogie do „masek” z Opola przywołuje się słowiańskie rzeźby i figurki, które w literaturze łączy się ze sferą dawnych wyobrażeń religijnych i z czynnościami kultowymi (Cehak-Hołubowiczowa 1965, s. 311-312; Gediga 2012, s. 125; Szczepanik 2020, s. 173). Porównanie znalezisk z Ostrówka do takich zabytków ma, jak można się domyślać, potwierdzić związek „masek” ze światem słowiańskich wyobrażeń abstrakcyjnych. Jednak sam 


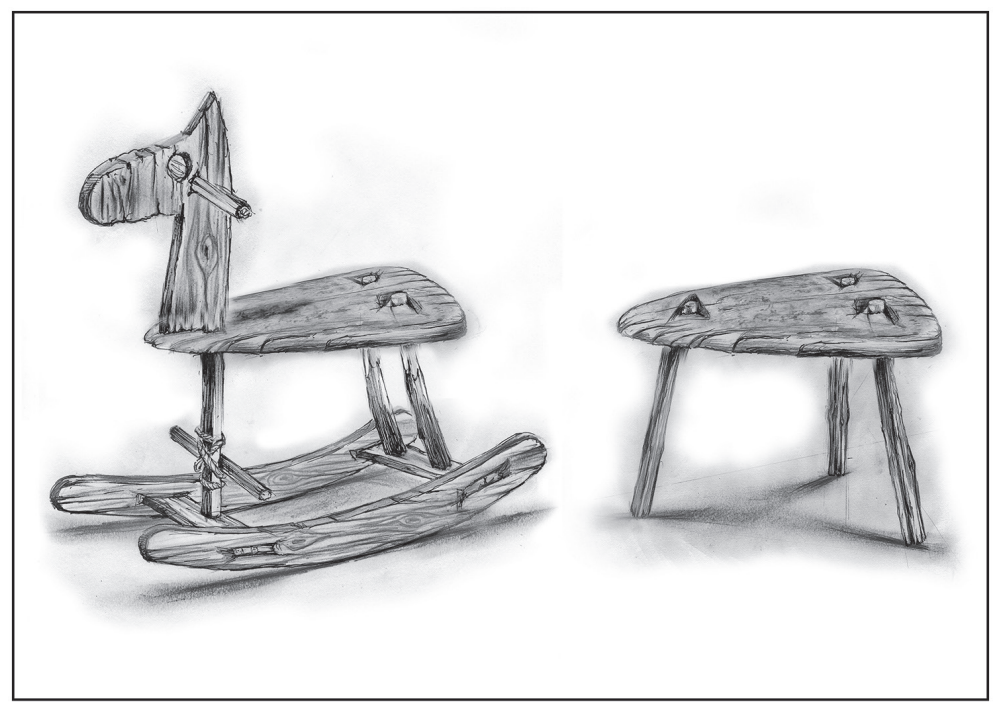

Ryc. 12. Graficzna wizualizacja hipotetycznej funkcji tzw. maski z Opola.

Rys. K. Szott

Fig. 12. Graphic visualization of the hypothetical function of the so-called mask from Opole.

Drawing by K. Szott

tylko trójkątny zarys twarzy, jaki stał się podstawą tych porównań, nie może być wskazówką ani co do kultowego charakteru jakiejś rzeźby, ani tym bardziej maski. Możemy tu jedynie mówić o pewnym obecnym w sztuce kanonie modelowania głowy. W żadnym wypadku nie można go uważać za cechę dystynktywną dla słowiańskich wyobrażeń religijnych per se, co powoduje, że i ten kierunek argumentacji należy uznać za przynajmniej dyskusyjny.

W kontekście powyższych ustaleń pozostaje stwierdzić, że nie mamy solidnych podstaw, aby podtrzymać hipotezę uznającą dwa zagadkowe przedmioty odkryte podczas badań wykopaliskowych grodu na Ostrówku w Opolu za maski. I to bez względu na to, czy będziemy mieć tutaj na myśli rekwizyty zakładane na twarz, czy też służące odwzorowaniu w formie symbolicznej postaci ludzkich bądź zwierzęcych mających na celu realizację czynności obrzędowych. Biorąc pod uwagę zarówno miejsce depozycji, jak i zalegający w tej samej warstwie kulturowej zespół źródeł ruchomych należałoby uznać je za destrukty przedmiotów wykorzystywanych w codziennych obowiązkach osoby/osób użytkujących stojące tu pierwotnie budynki. Czy były to elementy mebli, pozostałości zabawek czy przedmiotów wykorzystywanych przy pracy (jak np. ryczka) (ryc. 12) - nie sposób odpowiedzieć. Tym bardziej, że obecny zasób wiedzy na temat wyposażenia wczesnośredniowiecznych zachodniosłowiańskich domostw jest daleki od zadowalającego (por. Biermann 2020, s. 34). Niemniej jednak, w moim przekonaniu, taki sposób interpretacji, zwłaszcza biorąc pod uwagę niezwykle bogaty asortyment drewnianych przedmio- 
tów, jakie odkryto podczas badań archeologicznych Ostrówka (Hołubowicz 1956; Bukowska-Gedigowa, Gediga 1986), znajduje lepsze uzasadnienie aniżeli postrzeganie ich jako masek obrzędowych.

\section{MASKI ZDEMASKOWNE}

Odkryte przed półwieczem „maski” z Opola, ze względu na atrakcyjność wiązanych z nimi znaczeń, szybko weszły do obiegu naukowego, stając się jedną z ikon współczesnych badań nad wierzeniami i obrzędowością przedchrześcijańską wczesnośredniowiecznych Słowian. Na stałe zadomowiły się również w kulturze popularnej, stanowiąc oczywisty element dawnych wierzeń oraz prób (od)tworzenia pogańskiej obrzędowości.

Krytykę dominujących w literaturze ustaleń zaczęliśmy od zasadniczego problemu, jakim stała się potrzeba zdefiniowania pojęcia maski. Szybko okazało się, że nie chodzi tu o pytanie, co to jest maska, bo odpowiedź - mimo rozmaitych rozbieżności - zawsze łączy się z fenomenem zakrywania twarzy. Ważniejszą rolę odgrywa tu zagadnienie, c z y m ona jest/była. Prowadzone od wielu lat badania ogniskujące się wokół tak ujętego tematu biegną różnymi torami. Inaczej tłumaczą go antropolodzy kultury, inaczej teatrolodzy, a jeszcze inaczej religioznawcy. Jeśli jednak mielibyśmy dla wszystkich tych ustaleń znaleźć wspólny punkt, to byłby nim niewątpliwie wniosek, że maska jest przedmiotem nie tyle - czy może nie tylko - przysłaniającym twarz, ile ją zastępującym, jednocześnie biorąc na siebie dalsze funkcje komunikacyjne. Jest to więc przedmiot o ściśle określonej mocy sprawczej/performatywnej.

Wyniki analizy źródeł pisanych dały także podstawy do wydzielenia dwóch kategorii scenariuszy obrzędowych, w których mogły być wykorzystywane maski: kultowego i magicznego. Niestety, tropy prowadzące ku pierwszemu, w przypadku wczesnośredniowiecznej Słowiańszczyzny, są bardziej niż nikłe. Odnajdujemy je wyłącznie w kronice Kosmasa. Co prawda Czecha z pochodzenia, jednak kształconego poza granicami ojczystych ziem. Powoduje to, że nie wiemy, czy wszystkie przekazane informacje są obrazem rzeczywistości, czy też mamy do czynienia z relacją wzbogaconą erudycją autora. Nie mniej istotne jest również to, że dziejopis pisze o wydarzeniach z końca XI w., a więc blisko 200 lat po oficjalnej chrystianizacji ziem nad Wełtawą. Tym samym nie potrafimy powiedzieć, czy Kosmas opisuje obrzęd religijny o tradycjach sięgających pogańskiej przeszłości, czy też współczesne mu czynności magiczne, jakie znamy ze źródeł późniejszych. Pewną wskazówką może być tutaj co prawda daleki od oczekiwanego stosunek do chrześcijaństwa oraz sposób jego wdrażania przez Przemyślidów (Matla 2017, s. 80 n.; Małachowski 2018, s. 70), jest to jednak wskazówka tylko pośrednia i trudno, aby przesądzała sprawę (nawet jeśli podeprzemy ją - równie dyskutowanymi - źródłami dotyczącymi zwyczajów ludów germańskich). Mocniejsze oparcie dają tutaj znane ze Słowiańszczyzny wyobrażenia ikonograficzne, na których pojawiają się postaci o zoomorficznych cechach twarzy czy wręcz zwierzęcych pyskach. Analiza obecnych na nich wątków 
narracyjnych oraz porównanie z zabytkami skandynawskimi skłaniają do uznania $\mathrm{w}$ nich wizualizacji ceremonii religijnych. Kłopot $\mathrm{w}$ tym, że nie sposób ocenić, czy widzimy na nich ludzi w maskach, czy może istoty nadprzyrodzone. Dalszych trudności nastręcza identyfikacja etnokulturowa większości przedmiotów, na których owe wątki się pojawiły, gdyż nie potrafimy powiedzieć, kto je wykonał, kto ich używał, ani też co dla tej osoby/osób oznaczały. W końcu, co i komu miały komunikować? Na tym etapie wiedzy należy przyjąć, że mogły to być równie dobrze wątki obrazujące słowiańskie, jak i skandynawskie formy obrzędowości. Definitywne rozstrzygnięcie tego problemu wydaje się obecnie niemożliwe.

Drugą i znacznie lepiej poświadczoną kategorią zachowań obrzędowych wyłaniającą się z kart źródeł pisanych są wydarzenia, jakie rozgrywały się w okresie bożonarodzeniowo-noworocznym. W zasadzie wszystkie przytoczone zapisy potępiają „,bezeceństwa”, jakich lud w asyście duchownych dopuszczał się w kościołach i/lub na cmentarzach. Przy okazji dowiadujemy się, że ważną rolę odgrywały w nich maski/kostiumy i maszkary. Szczegóły, jakie zdradzają autorzy analizowanych opisów, pozwalają uznać, że relacjonują oni czynności obrzędowe związane z magią rezurekcyjno-płodnościową. Nie dają jednak odpowiedzi, na ile były to zwyczaje zakorzenione w starszej, na ile zaś we współczesnej im tradycji. Do tych ostatnich zaliczyć należy miejsce obchodów świąt, jakim było wnętrze kościoła. Jest to dla nas o tyle istotne, że jeśli - podobnie zresztą jak przykościelny cmentarz - był to obszar nacechowany sacrum, to nie był przestrzenią dawnych hierofanii - a tylko tutaj mogły być realizowane wydarzenia kultowe kierowane ku pogańskim bóstwom. Takich przestrzeni w XIII w. (przynajmniej na ziemiach ówczesnej Polski i Czech) już nie było. Tym samym dostajemy do rąk kolejną wskazówkę wykreślającą noworoczne zachowania obrzędowe $\mathrm{z}$ dawnych praktyk o charakterze religijnym. Można natomiast dopuścić obecność tradycji przedchrześcijańskich w adaptującej się do nowych warunków obrzędowości magicznej. I nie był to - jak widzieliśmy - fenomen tylko słowiański, ale dobrze poświadczony dla obrzędowości rezurekcyjnej całej ówczesnej (przynajmniej formalnie) chrześcijańskiej Europy.

Niedużo więcej do podjętych zagadnień wniosła analiza znanych dziś znalezisk archeologicznych zidentyfikowanych jako maski. Ocena zabytków wraz z kontekstem ich odkrycia powoduje, że i tak niezbyt obszerny korpus źródeł trzeba było jeszcze uszczuplić. Po przeprowadzonej krytyce ostały się wyłącznie maski wydobyte w trakcie badań Nowogrodu Wielkiego, Lukovca oraz Hedeby (choć w tym przypadku wtórne użycie ich do uszczelnienia poszycia łodzi pozwoliło na włączenie ich tylko do studiów formalnych). Informacje wynikające z publikacji okoliczności odkrycia egzemplarzy ruskich nie dały wiele możliwości interpretacyjnych. Zaleganie w różnych miejscach przestrzeni osadniczej, brak danych wskazujących na intencjonalny depozyt oraz na temat innych przedmiotów zalegających w tym samym kontekście stratygraficznym skłaniają do wniosku, że należy je uznać za zguby. Niewykluczone, że upuszczone podczas obchodów świąt połączonych z kolędowaniem.

Dzięki wszystkim tym ustaleniom pozwalającym na określenie, w jaki sposób maska mogła być percypowana przez społeczności wczesnośredniowieczne, jaki 
nosić status i w jakich potencjalnie formach obrzędowości być wykorzystywana, otrzymaliśmy odpowiednie narzędzia, aby zmierzyć się z problemem identyfikacji znalezisk z Opola.

Interpretacja zaproponowana przez $\mathrm{H}$. Cehak-Hołubowiczową, mimo że niepozbawiona luk (z czego zdawała sobie sprawę sama badaczka), okazała się na tyle atrakcyjna, że nigdy nie doczekała się krytycznego ujęcia. Kolejni autorzy, nie zwracając uwagi na „chwiejne” podstawy proponowanych rozwiązań, podpierając je kolejnymi argumentami i (nad)interpretacjami, doprowadzili do wytworzenia swoistego aksjomatu badawczego. Ponowna analiza cech metrycznych, wyglądu oraz kontekstu odkryć wsparta wynikami studiów porównawczych wykazała, że nie ma on mocnych podstaw, a przedmioty określane mianem masek z Opola należy uznać za destrukty elementów umeblowania lub przedmiotów wykorzystywanych w gospodarstwie domowym. Tym samym należy wykreślić je $\mathrm{z}$ korpusu zabytków mogących mieć związek z życiem religijnym wczesnośredniowiecznych Słowian.

\section{Podziękowania:}

Za cenne uwagi i pomoc w pracy nad artykułem pragnę złożyć wyrazy wdzięczności i serdeczne podziękowania mgr. Krystianowi Chrzanowi, dr. hab., prof. IAE PAN Andrzejowi Janowskiemu, Klaudii Karpińskiej, dr. Aleksandrowi Limisiewiczowi, prof. dr. hab. Sławomirowi Moździochowi, prof. dr. hab. Marianowi Rębkowskiemu, Karolowi Szottowi i Sławomirowi Uta.

\section{WYKAZ CYTOWANEJ LITERATURY}

\section{Źródła}

Codex

Kos m as

Mikołaj z Błonia

Michał z Janowca

V P

- Codex Diplomaticus Maioris Poloniae documenta, et jam typis descripta, et adhuc inedita complectens, annum 1400 attigentia. Editus cura Societatis Literariae Posnaniensis. T. 2, Poznaniae 1878.

- Kronika Czechów, wyd. M. Wojciechowska, Wrocław 2006.

- Tractatus sacerdotalis de sacramentis deque divinis officiis et eorum administrationibus, Cracoviae 1519.

-Kazania wielkopostne (rok 1490), [w:] Glosy polskie w łacińskich kazaniach średniowiecznych, 1, E. Balcarzowa wyd., Wrocław 1981.

- Żywot z Prüfening Ottona z Bambergu, [w:] Pomorze zachodnie w żywotach Ottona, J. Wikarjak wyd., Warszawa 1979.

\section{Opracowania}

A a n e st a d H. L. 2018, Charisma, violence and weapons. The broken swords of the Vikings, [w:] Charismatic objects. From roman times to middle ages, M. Vedeler, I.M. Røstad, E. Siv Kristoffersen, Z.T. Glørstad red., Oslo, s. 147-166. 
A lcorta C. A. S o s is R. 2005, Ritual, emotion, and sacred symbols. The evolution of religion as an adaptive complex, „Human Nature” 16/4, s. 323-359.

A ld hou s e Green M. 2005, An archaeology of images. Iconology and cosmology in Iron Age and Roman Europe, London-New York.

A v i e r i n c e v S. 1994, Bachtin, śmiech i kultura chrześcijańska, „Znak” 9, s. 86-99.

B a ck D a n i els s o n I. - M., 2007. Masking moments. The transitions of bodies and beings in late Iron Age Scandinavia, Stockholm.

B án kow ski A . 2000, Etymologiczny słownik języka polskiego, t. 2, Warszawa.

B e r w i ń s k i R. 1862, Studia o gusłach, czarach, zabobonach i przesqadach ludowych. Tom I, Poznań.

B i e r m a n n F. 2020, Osady otwarte, miejsca handlowe i grody-osadnictwo Słowian w pótnocno-wschodnich Niemczech, [w:] Stowianie połabscy, Collectio Cathalogorum Gnesnensium 2, Ł. Kaczmarek, P. Szczepanik red., Gniezno-Szczecin, s. 25-48.

B o h ol m ̊̊. 2010, Weneckie widowiska karnawałowe w maskach, [w:] Antropologia widowisk. Zagadnienia i wybór tekstów, L. Kolankiewicz red., Warszawa, s. 694-703.

B rege $\mathrm{nh} ø \mathrm{j}$ C. 2012, The masks of Hedeby in historic and ethnological perspective, [w:] Masken der Vorzeit in Europa (II). Internationale Tagung vom 19. bis 21. November 2010 in Halle (Saale), H. Meller, R. Maraszek red., Halle, s. 111-120.

Brett G., Macaulay W.J., S teven s on R. B. 1947, The Great Palace of the Byzantine emperors. Being a first report on the excavations carried out in Istanbul on behalf of the Walker Trust (The University of St. Andrews) 1935-1938, Oxford.

B r ü ckn e r A . 1985, Słownik etymologiczny języka polskiego (wyd. IV), Warszawa.

B ukowska-Gedigowa J., Gediga B. 1986, Wczesnośredniowieczny gród na Ostrówku w Opolu, Wrocław.

B u k o w s k i Z. 1960, Puste kabłączki skroniowe typu pomorskiego, Szczecin.

B u r c h a r d t J. 1986, Dlaczego pogańscy Polanie w XI w. nie zniszczyli katedry gnieźnieńskiej? „Literatura Ludowa”, 1, s. 31-42.

B yl in a S. 1992, Człowiek i zaświaty. Wizje kar pośmiertnych w Polsce średniowiecznej, Warszawa.

B ylin a S. 2009, Religijność późnego średniowiecza. Chrześcijaństwo a kultura tradycyjna $w$ Europie środkowo-wschodniej $w X I V-X V$ w., Warszawa.

C ehak-Hołubowiczowa H. 1965, Drewniane maski z grodu-miasta na Ostrówku w Opolu, „Archeologia Polski”, 10/1, 305-317.

Cetwiński M., De r wi ch M. 1987, Herby, legendy, dawne mity, Wrocław.

D e ka n J. 1979, Wielkie Morawy. Epoka i sztuka, Bratysława.

D o rka G. 1939, Urgeschichte des Weizackerkreises Pyritz, Stettin.

D u l u a r e J.A. 2009, O bóstwach płodności albo o kultach fallicznych dawnych i współczesnych, Kęty.

F i l i p o w i a k W. 1988, Źródła archeologiczne, archeozoologiczne i onomastyczne w problematyce kultowej Pomorza Zachodniego, [w:] Myśl przez pryzmat rzeczy, Scripta Archaeologica III, Z. Kobyliński, B. Lichy, P. Urbańczyk red., Warszawa, s. 88-96.

F i l i p o w i k W. 1993, Słowiańskie wierzenia pogańskie u ujścia Odry, [w:] Wierzenia przedchrześcijańskie na ziemiach polskich. Materiały z Sesji Archeologicznej zorganizowanej przez Muzeum Archeologiczne w Gdańsku w dniach 15-16 101987 roku, M. Kwapiński, H. Paner red., Gdańsk, s. 19-46.

Fili p ow iak W., Szydłowski M. 2019, Stone artefacts, [w:] Wolin - the Old Town. Vol. II. Studies on finds, M. Rębkowski, red., Szczecin, s. 221-244.

Gard eła L. 2106, (Magic) Staffs in the Viking Age, Wien. 
Gardeła L., Kajkowski K., Ratajczyk Z. 2019, Ostrogi zoomorficzne z Ciepłego. Zachodniosłowiański model kosmosu?, „Pomorania Antiqua”, 28, s. 65-152.

Gediga B. 1996, Chrystianizacja i utrzymywanie się przedchrześcijańskich praktyk kultowych na Śląsku, [w:] Słowiańszczyzna w Europie, 1, Z. Kurnatowska, red., Wrocław, s. $159-167$.

Ge diga B. 2012, Frühmittelalterliche Holzmasken aus Opole-Ostrówek, [w:] Masken der Vorzeit in Europa (II). Internationale Tagung vom 19. bis 21. November 2010 in Halle (Saale), H. Meller, R. Maraszek red., Halle, s. 121-127.

G i r a r d R. 1993, Sacrum i przemoc, Poznań.

Gloge r Z. 1903, Encyklopedia staropolska. Ilustrowana, IV, Warszawa.

Gri n s ell L. V. 1961, The breaking of objects as a funerary rite, „Folklore”, 72/3, s. 475-491.

Gunnell T. 2007, Introduction, [w:] Mask and mumming in the Nordic area, T. Gunnell red., Uppsala, s. 27-43.

G u n ell T. 2012, Masks and performance in the early Nordic world, [w:] Masken der Vorzeit in Europa (II). Internationale Tagung vom 19. bis 21. November 2010 in Halle (Saale), H. Meller, R. Maraszek red., Halle, s. 183-196.

Har n t oll P. red. 1967, The Oxford companion to the theatre, Oxford.

Häg g I. 1984, Die Textilfunde aus dem hafen von Haithabu, Berichte über die Ausgrabungen in Haithabu, Bericht 20, Neumünster.

He de a e r L. 2011, Iron Age myth and materiality. An archaeology of Scandinavia AD 400-1000, London-New York.

H e n s el W. 1984, Skad przybyli Słowianie, Wrocław.

Hoł u b ow ic z W. 1956, Opole w wiekach X-XII, Katowice.

H o m e r 2000, Odyseja, przekł. L. Siemieński, Gdańsk.

Ka j k ow ski K. 2017, Mity, kult i rytuał. O duchowości nadbałtyckich Słowian, Szczecin.

Ka ź m i e r czyk J. 1993, Ku początkom Wrocławia. Cz. 2, Warsztat budowlany i kultura mieszkalna Ostrowa Tumskiego od połowy XI do połowy XIII wieku, Wrocław.

Kerényi K. 2010, Człowiek i maska, [w:] Antropologia widowisk. Zagadnienia i wybór tekstów, L. Kolankiewicz red., Warszawa, s. 683-693.

K i e r s n o w ski R. 1990, Niedźwiedzie i ludzie w dawnych i nowszych czasach, Warszawa.

K in keld e y T. 2008, Figürliche Darstellungen auf mittelslawischer Keramik vom Burgwall Repten bei Calau, [w:] „Die Dinge beobachten... “. Archäologische und historische Forschungen zur frühen Geschichte Mittel- und Nordeuropas. Festschrift für Günter Mangelsdorf zum 60. Geburtstag, F. Biermann, U. Müller, T. Terberger red., Rahden, s. 497-501.

Kol a n ki e w i c z L. 2020, Dziady. Teatr święta zmarłych, Gdańsk.

Kolč in B.A. red. 1985, Drevnij Novgorod: prikladnoe iskusstvo i arheologiâ. Raskopy, gramoty, pismennost', muzykalnye instrumenty, maski, šahmaty, vislye pečati, cvetnoj metal, kost', derevo, steklo, ântar', kamen', glina, koža, železo, Moskva.

Ko r o l e n k o C. P. 2006, The revival of pagan traditions and their influence on the content of mental disorders in contemporary Russia, „World Cultural Psychiatry Research Review” 2006, s. 1-20.

Ko w a li k A . 2004, Kosmologia dawnych Słowian. Prolegomena do teologii politycznej dawnych Słowian, Kraków.

K u ch a r s k a J. 1991, Puste noce jako zespół ludowych rytuałów, obyczajów, zwyczajów w procesie zmian współczesnych, „Łódzkie Studia Etnograficzne” 30, s. 5-23.

Ku ra s ińs k i T. 2011, Łamanie, zginanie, wbijanie. O kilku nietypowych zabiegach dotyczacych uzbrojenia na wczesnośredniowiecznych cmentarzyskach szkieletowych z ziem polskich, 
[w:] Non sensistis gladios. Studia ofiarowane Marianowi Głoskowi w 70. rocznice urodzin, O. Ławrynowicz, J. Maik, P.A. Nowakowski red., Łódź, s. 219-236.

L a r s o n F. 2017, Historia świata przez ścięcie głowy opisana, Warszawa.

Van der Lee uw G. 1978, Fenomenologia religii, Warszawa.

L e $\mathrm{m}$ m T. 2007, Maskendarstellungen der Wikingerzeit, „Offa“61/62, s. 309-352.

L é vi - S t r a u s C C. 1985, Drogi masek, Łódź.

L i s s a u e r A . 1892, Über einige westpreußische Bronzeringe und deren Verbreitung, „Verhandlungen der Berliner Gesellschaft für Anthropologie, Ethnologie und Urgeschichte", s. 469-476.

Łęg a W. 1929, Kultura Pomorza we wczesnem średniowieczu na podstawie wykopalisk, cz. I, „Roczniki Towarzystwa Naukowego w Toruniu” 35, s. 153-446.

Ma e rt e n s J.- T. 2010, Maska i lustro. Esej z antropologii okrycia twarzy, [w:] Antropologia widowisk. Zagadnienia i wybór tekstów, L. Kolankiewicz red, Warszawa, s. 704-718.

Mała ch ow ski R. 2018, Rygoryzm religijny w Czechach i Polsce w początkowym okresie chrystianizacji, [w:] Animos labor nutrit. Studia ofiarowane Profesorowi Andrzejowi Buko $w$ siedemdziesiąta rocznicę urodzin, T. Nowakiewicz, M. Trzeciecki, D. Błaszczyk red., Warszawa, s. 65-72.

Mat la M. 2017, Czeskie wpływy w życiu religijnym i piśmiennictwie państwa piastowskiego w X-XI wieku. Poznań.

Mo s z y ń s k i K. 1968, Kultura ludowa Słowian, 2. Kultura duchowa, 2, Warszawa.

O d y n i e c W. 1985, Kaszubskie obrzędy i obyczaje, Gdańsk.

Ols z e w ska-D y o n i zi a k B . 2001, Człowiek-kultura-osobowość. Wstęp do klasycznej antropologii kulturowej, Wrocław.

Ols z e w ski M. 2002, Świat zabobonów w średniowieczu. Studium kazania O zabobonach Stanisława ze Skarbimierza, Warszawa.

O t t o R. 1993, Świętość. Elementy racjonalne i irracjonalne w pojęciu bóstwa, Wrocław.

Ovč in nikova B. B. 2013, Licevye maski v srednevekovoj kul'ture Rusi (po materialam Novgorodskoj arheologičeskoj èkspedicii, [w:] Arheologiâ severa Rossii. Ot èpohi železa do Rossijskoj imperii. Materialy Vserossijskoj naučnoj arheologičeskoj konferencji, V.A. Borzunov red., Ekaterynburg-Surgut, s. 227-232.

Ovčinnikova B. B., Ko pnina E. V. 2000, Maski i ih rol'v srednevekovoj kul'ture Novgoroda, [w:] Problemy istorii Rossii. 3. Novgorodskaâ Rus'. Istoričeskoe prostranstvo i kul'turnoe nasledie, A.T. Šaškov red., Ekaterynburg, s. 118-134.

$\mathrm{Palu}$ ch A. 1995, Etnograficzny atlas ciała ludzkiego i chorób, Wrocław.

P e r s z o n J. 1999, Na brzegu życia i śmierci. Zwyczaje, obrzędy oraz wierzenia pogrzebowe i zaduszkowe na Kaszubach, Lublin.

Plus kow ski A., P a tri ck P. 2003, 'How do you pray God?' Fragmentation and variety in Early Medieval Christianity, [w:] The cross goes North. Processes of conversion in northern Europe, AD 300-1300, M. Carver red., York, s. 29-57.

Pollingt on S. 2011, The elder gods. The Otherworld of early England, Little Downham.

P o r a z i ń s k i J. 2015, Staropolska kultura śmiechu. Ludzie - teksty - konteksty, Toruń.

Porębska-Kubik E., Marcinkowska T. 1992, Maska wobrzędzie, Kraków.

P os s elt N., S z c z e p a n i P. 2017, Zoomorphe Applikationen und Darstellungen auf slawischen Schläfenringen im nördlichen westslawischen Raum, [w:] Religion und Gesellschaft im nördlichen westslawischen Raum. Beiträge der Sektion zur slawischen Frühgeschichte der 22. Jahrestagung des Mittel- und Ostdeutschen Verbandes für Altertumsforschung in Chemnitz, 29.-31. März 2016, F. Biermann, T. Kersting and A. Klammt red., Langenweissbach, s. 193-220. 
P r i c e N. 2002, The Viking way. Religion and war in late Iron Age Scandinavia, Uppsala.

S ch in d le r N. 2010, Aspekty historyczno-antropologicznej teorii karnawatu, [w:] Antropologia widowisk. Zagadnienia i wybór tekstów, L. Kolankiewicz red., Warszawa, s. 43-437.

S ch m it t J. C. 2006, Gest w średniowiecznej Europie, Warszawa.

S ch u m a n P. 1897, Die Kultur Pommerns in vorgeschichtlicher Zeit, Berlin.

S e m ple S. 1998, A fear of the past: the place of the prehistoric burial mound in the ideology of middle and later Anglo-Saxon England, „World Archaeology”, 30/1, s. 109-126.

S ł u p e ck i L. P. 2016, "Til holtz ek gekk ok til hrás viðar, gambantein at geta..." Siła życiowa drzemiaca $w$ drewnie i jak ja postrzegano $w$ dawnych wierzeniach. Skąd brała się moc drewnianej różḋ̇ki, [w:] Gdy umiera człowiek, umiera świat cały, Funeralia Lednickie, spotkanie 18, W. Dzieduszycki, J. Wrzesiński, red. Poznań, s. 65-69.

S t a n isław ski B. 2013a, Jómswikingowie z Wolina-Jómsborga - studium archeologiczne przenikania kultury skandynawskiej na ziemie polskie, Wrocław.

St a n i sław ski B. 2013b, Norse culture in Wolin-Jómsborg, [w:] Scandinavian culture in Medieval Poland, Interdisciplinary Medieval Studies II, S. Moździoch, B. Stanisławski, P. Wiszewski red., Wrocław, s. 193-246.

St a $\mathrm{n}$ i sła w ski B. 2013c, Wstęp do archeologii wczesnośredniowiecznego Wolina, [w:] Wolin wczesnośredniowieczny, część 1, Origines Polonorum, VI, B. Stanisławski, W. Filipowiak red., Warszawa, s. 13-42.

St el m a ch ow ska B. 2016, Rok obrzędowy na Pomorzu, Gdynia.

S z a f r án ski W. 1979, Pradzieje religii w Polsce, Warszawa.

S z c z e p a n i k P. 2020, Wczesnośredniowieczne maski Słowian. Obrazy zmarlych, bogów, czy rekwizyty rytualne? „Przegląd Archeologiczny”, 68, s. 163-186.

Szyje wski A. 2003, Religia Słowian, Kraków.

Toynbee A., Mant A.K., Smart N., Hinton J., Yudkin S. 1973, Człowiek wobec śmierci, Warszawa.

U r b a ń c z y k P. 2020, Trudna historia zwłok, t. 1: „Wrócisz do ziemi”, Toruń.

U r b a ń c z y k S. 1980, Ze studiów nad dawna religią Stowian (Komentarz do „Kroniki czeskiej” Kosmasa, ks. III, r. 1), „Slavia Antiqua”, 27, s. 191-195.

Vu l cã n e s c u R. 1979, Kolumna niebios, Warszawa.

Walt e r P. 2006, Mitologia chrześcijańska. Święta, rytuały i mity średniowiecza, Warszawa. W i t e l o 1979, List Witelona do Ludwika we Lwówku Śląskim. Problematyka teoriopoznawcza, kosmologiczna i medyczna, Studia Copernicana, 19, G. Burchardt wyd., Warszawa.

Wrze s i ń s k i J. 1989, „Koziołek Lednicki”-problemy z XIX-wiecznymi znaleziskami, „Studia Lednickie", 1, s. 163-170.

KAMIL KAJKOWSKI

\section{MASKS FROM OPOLE IN THE CONTEXT OF MEDIEVAL SLAVIC RITES}

\section{Sum mary}

The two artifacts identified as remains of masks were excavated at the Ostrówek archaeological site in Opole in 1959 and in 1962 (Figs 1-4; 10; 11). The finds were believed to be props used in ritual activities and thus a relic of the spiritual life of the early medieval inhabitants of the 
stronghold. The interpretation turned on traits considered as anthropomorphic: a shape resembling a human face and holes apparently rendering physiognomic features (eyes and mouth). For lack of direct parallels, the researcher, Helena Cehak-Hołubowiczowa, based her identification on ethnographical sources in the form of modern masks of carolers collected by Kazimierz Moszyński and referred the find context to this idea, apparently confirming well the essence of her reasoning. The attractiveness of this interpretation quickly made it part of studies on Slavic pagan beliefs. Accepted and repeated by other researchers, it established masks as an unquestioned element of the religious life of these communities. In consequence, later discussions of the place of these objects within the sphere of abstract ideas focused not on wh e the r they played an active role in rituals but rather when and whe re they were used. Some researchers considered them as props when going around with a goat/caroling, while others linked them to a cult of the dead. These suggestions were all based on, as it turned out, weak grounds, often overlooking sources that could undermine a given view. By the same, the quoted written accounts concerned Polish lands to the exclusion of all others and were limited always to the same three: the Chronica Boemorum written by the priest, writer and historian Cosmas of Prague, a letter from Pope Innocent III to Archbishop Henryk Kietlicz (1207), and two other letters from Pope Gregory IX to the monastic orders active in Poland (1230). This specific selection of historical sources shaped conclusions on the importance of masks in the religious rituals of $11^{\text {th }}$-century Slavs (Cosmas) and for another 150 years despite a well established Christian faith. This highly attractive reasoning is countered by the content of different historical source, which indicate that the phenomenon was neither exclusively local nor even exclusively medieval. There is also a great deal to suggest that events from the end of the $11^{\text {th }} \mathrm{c}$. cannot be equated with the beginning of the $12^{\text {th }} \mathrm{c}$. Polish research on ritual masking of the face has yet to incorporate the results of studies on iconographic sources, which are important in that they offer information for more detailed studies confirming the use of masks in religious rituals and helping to establish the characteristics of these artifacts as three-dimensional and zoomorphic objects (they did not contribute anything significant to research of a more general nature). Interesting data has come from studies of archaeological masks, even though the corpus of finds of this kind is very small (Figs 5-7; 9), and was restricted even further following a detailed analysis of the artifacts and their find context. It is now made up of examples from Veliky Novgorod, Lukovec and Hedeby. A review of the material led to a few important generalities. For one, none of the artifacts known today was found in a place interpreted as an area where religious ceremonies were celebrated. Neither did the find context in any of these cases bear resemblance to an intentional deposit. Apart from the reused examples from Hedeby, the other masks were either lost or thrown away. There is much to suggest that they had a role in magical rites during the solstice. The outcome of this review of the source material has contributed more than just remarks of a general nature. It has led to the identification of certain features characterizing masks and the ideas inherent to them, and provided grounds for a revision of views on the primary function of the finds from Opole. A new examination of the execution, decoration and finishing of the finds has not found enough supporting evidence for considering them as anthropomorphic objects or for attributing to them any non-utilitarian function. The same should be said about the find contexts, which do not underpin any associations with abstract ideas and even more so with any kind of power of communication with the sacrum. All things considered, the finds from Opole were not masks in all likelihood, but rather destroyed elements of furniture or some other objects of everyday use belonging to the inhabitants of the Ostrówek stronghold (Figs 8; 12).

Translated by Iwona Zych 